\title{
Agronegócio e agricultura familiar no Brasil: desafios para a transformação democrática do meio rural
}

\section{Agribusiness and family agriculture in Brazil: challenges for the democratic transformations of the rural area}

Nelson Giordano Delgado - Professor Associado II do Curso de Pós-Graduação de Ciências Sociais em Desenvolvimento, Agricultura e Sociedade da Universidade Federal Rural do Rio de Janeiro (CPDA/UFRRJ), Brasil. E-mail: nelsongdelgado@gmail.com

\begin{abstract}
Resumo
O objetivo deste artigo é fazer uma revisão da evolução das relações entre a agricultura e a economia no Brasil desde a década de $1980 \mathrm{com}$ interesse de enfatizar o que consideramos obstáculos e oportunidades surgidos desde então para a transformação democrática do meio rural. $\mathrm{O}$ artigo mostra a política macroeconômica dos anos 1980 como condicionante do desenvolvimento agrícola e rural, impondo ajustamento externo à economia e à sociedade brasileiras, levando a agricultura a ser constrangida a produzir consideráveis superávits em sua balança comercial, visando garantir o ajustamento da balança de pagamentos do país. A hipótese é que no meio rural, o projeto neoliberal tem sido representado pelo chamado agronegócio, considerado como um bloco de poder, fortalecido desde aquele ajuste externo. Porém argumenta que os principais protagonistas do projeto democratizante no meio rural foram os sem-terra, assentados e agricultores familiares, nas lutas da década de 1990, com propostas alternativas de desenvolvimento rural baseadas na reforma agrária e no fortalecimento da agricultura familiar. A atuação desses atores sociais acabou conformando o reconhecimento público da presença de "duas agriculturas" que se autodefinem como tal: a do agronegócio e a da agricultura familiar.
\end{abstract}

\section{Palavra-chave}

Relação agricultura e economia. Agricultura familiar. Agronegócio. Lutas rurais. Brasil.

\begin{abstract}
The aim of this paper is to review the development of relations between agriculture and the economy in Brazil since the 1980s with interest to emphasize what we consider obstacles and opportunities that have arisen since then for the democratic transformation of the countryside. The article shows the macroeconomic policy of the 1980s as conditioning the agricultural and rural development, imposing external adjustment to the Brazilian economy and society, bringing agriculture to be constrained to produce substantial surpluses in its trade balance in order to ensure the adjustment of the balance of payments the country The hypothesis is that in rural areas, the neoliberal project has been represented by so called agribusiness, regarded as a power bloc, strengthened since that external adjustment. However the article argues that the main protagonists of the democratizing project in rural areas were the landless, settlers and family farmers in the struggles of the 1990s, with alternative proposals for rural development based on land reform and strengthening of family farming. The action of these social actors formed the public recognition about the presence of "two agricultures" which define themselves as such: the agribusiness and family farming.
\end{abstract}

\section{Keywords}

Relation agriculture and economy. Family farming. Agribusiness. Rural struggles. Brazil. 


\section{INTRODUÇÃO}

O objetivo deste texto é fazer uma revisão da evolução das relações entre a agricultura e a economia no Brasil, desde a década de 1980, tendo em vista enfatizar o que consideramos obstáculos e oportunidades surgidos desde então, para a transformação democrática do meio rural.

Neste sentido, enfatizamos, por um lado, a importância da política macroeconômica como condicionante do desenvolvimento agrícola e rural, especialmente como consequência do ajustamento externo imposto à economia e à sociedade brasileiras após a crise da dívida externa dos anos 1980 e a subsequente integração à globalização financeira e comercial na década de 1990. A partir daí, a agricultura tem sido constrangida e estimulada a produzir consideráveis superávits em sua balança comercial, de modo a garantir o ajustamento da balança de pagamentos do país. Nesta perspectiva, a "vocação agroexportadora" do país, tão cara historicamente às suas elites agrárias e agora também agroindustriais, tem sido atualizada para os tempos da globalização.

Por outro lado, a partir da metade da década de 1980, a economia e a sociedade brasileiras vêm sendo influenciadas e conformadas pela coexistência, por razões diversas, de dois projetos políticos em disputa. O projeto neoliberal, associado à restauração conservadora liderada mundialmente pelos Estados Unidos, e que se tornou dominante no país nos anos 1990, e o projeto democratizante - no sentido de que representa um processo que busca a democratização da sociedade, em suas múltiplas dimensões - desencadeado pela luta contra a ditadura militar e fortalecido pela redemocratização institucional ocorrida em 1985.

A hipótese com a qual trabalhamos e organizamos boa parte de nossa argumentação é que, no meio rural, o projeto neoliberal tem sido representado pelo chamado agronegócio, considerado no texto como um bloco de poder, que vem se fortalecendo desde o ajuste externo dos anos 1980 - embora tenha sido estimulado pela política estatal desde a modernização da agricultura na década de 1970 - e que ganha impulso, inclusive pela mídia, a partir do segundo governo Fernando Henrique Cardoso. Da mesma forma, argumentamos que os principais protagonistas do projeto democratizante no meio rural foram os semterra, assentados e agricultores familiares (e suas organizações representativas), identidades afirmadas na década de 1990, através da construção de propostas alternativas de desenvolvimento rural baseadas na reforma agrária, no fortalecimento e na consolidação da agricultura familiar.

O texto trabalha, então, provocativamente, com a suposição implícita de que a atuação dos atores sociais envolvidos e sua progressiva consideração pelo 
Estado e seu envolvimento com diferentes agentes da política governamental foi conformando o reconhecimento público da presença de "duas agriculturas" que se autodefinem como tal: a do agronegócio e a da agricultura familiar. Esse reconhecimento se expressa, inclusive, em nossa perspectiva, pela existência de dois ministérios que se envolvem principalmente com uma delas, definindo um conjunto de políticas públicas que se destinam atualmente de forma prioritária ao agronegócio, no caso do MAPA, e à agricultura familiar, à reforma agrária e aos povos e populações tradicionais existentes no meio rural, no caso do MDA. É indiscutível que essas agriculturas não são estanques, nem independentes, muito pelo contrário. E que mesmo no interior de cada uma delas a consideração da complexidade de atores, interesses e tensões é inevitável. Mas, neste texto, o que nos interessa acentuar, propositalmente, é que aparecem hoje no cenário nacional disputando políticas públicas e concepções diversas sobre o significado do desenvolvimento rural, da preservação do meio ambiente e da democratização da economia e da sociedade. E, a partir da metade dos anos 1980, os governos brasileiros, sem exceção, tiveram de fazer frente, de alguma forma, às suas reivindicações e aos projetos políticos a que estão associadas.

O ensaio inicia com uma discussão do processo de ajuste externo ocorrido na economia e na sociedade brasileiras na década de 1980, e suas consequências sobre o papel a ser desempenhado pela agricultura neste ajuste. São condicionantes internos importantes do comportamento verificado na década de 1980, o golpe militar de 1964, que eliminou as reivindicações de reforma agrária que eclodiram no início dos anos 1960, e abriu caminho para um processo conservador de modernização da agricultura na década de 1970, que trouxe resultados bastante penosos para os trabalhadores e pequenos produtores rurais e muito favoráveis às elites agrárias, agrícolas e agroindustriais. O item fecha com a constatação da revitalização dos movimentos sociais no meio rural e da complexificação dos personagens e das demandas do mundo do trabalho rural, com uma breve menção à tentativa fracassada de lançar um plano nacional de reforma agrária no governo da Nova República.

O item 2 examina a década de 1990, os efeitos deletérios da liberalização comercial e do desmonte da política pública sobre a agricultura e o "relançamento" do agronegócio por meio das políticas públicas do segundo Governo FHC e do comportamento do mercado internacional, reforçando e aprofundando sua importância na economia e na política brasileiras através de sua "imprescindibilidade" para manejar o ajustamento externo da economia. Neste item enfatizamos também o surgimento simultâneo dos dois projetos políticos mencionados anteriormente e seus desdobramentos no meio rural. 
No item 3 fazemos uma mais detalhada consideração acerca de algumas medidas e políticas do governo Lula frente ao agronegócio e ao projeto democratizante no meio rural. Neste sentido, tentamos sublinhar as diversas janelas de oportunidade abertas para este projeto, bem como as continuidades mantidas com o projeto neoliberal no meio rural, através principalmente do apoio dado ao agronegócio e da preservação de sua indispensabilidade na realização do ajustamento externo da economia brasileira.

Por fim, o texto encerra com alguns comentários, que buscam chamar atenção para alguns obstáculos, desafios e oportunidades para a transformação democrática do meio rural brasileiro.

\section{O AJUSTAMENTO DOMÉSTICO À CRISE EXTERNA NA DÉCADA DE 1980}

As condições de articulação, de financiamento e de continuidade do padrão de crescimento industrial que predominou no Brasil no pós-guerra, romperam-se definitivamente a partir do início da década de 1980, como consequência da crise da dívida externa e de suas principais formas de manifestação: a impossibilidade de acesso ao mercado internacional de crédito combinada com a elevação brusca da remessa de juros, por conta do enorme aumento das taxas internacionais; a profunda crise institucional e financeira do Estado nacional; e a aceleração vertiginosa da inflação ${ }^{1}$. Com isso, a política macroeconômica - especialmente monetária, fiscal e comercial - ficou refém da necessidade de viabilizar internamente os pagamentos relativos ao serviço da dívida externa e de impedir que o agravamento do endividamento público externo e da taxa de crescimento dos preços empurrasse a economia para a hiperinflação.

O resultado foi a adoção de uma política econômica recessiva, acompanhada por desvalorizações significativas da taxa de câmbio, com o objetivo de promover um amplo deslocamento de recursos dos setores produtores de bens para consumo doméstico para os setores voltados às exportações ou à substituição das importações, de modo que a possibilidade de retomada do crescimento econômico passasse a depender quase exclusivamente do comportamento do mercado externo,

1 Note-se que a crise da dívida externa foi provocada principalmente pelas mudanças na política econômica norte-americana no início dos anos 1980, que promoveram uma notável e imediata elevação das taxas de juros internacionais, como parte de um processo econômico, político e militar conhecido como a "retomada da hegemonia norte-americana" e que anunciou a imposição na economia internacional de uma política que passou a ser chamada de neoliberal (veja-se, a respeito, o artigo clássico de Tavares (1997), originalmente publicado em 1985). 
além de viabilizar uma transferência significativa de poupanças para o exterior, através da obtenção de superávits crescentes na balança comercial, da transferência de renda dos assalariados, por meio da aceleração inflacionária, e do desequilíbrio financeiro progressivo do setor público (intenso crescimento da dívida pública interna, concomitante à estatização da dívida externa).

No período 1978-1982, os juros pagos pelo Brasil aumentaram 282\% entre os dois anos extremos, como decorrência da violenta elevação das taxas de juros internacionais, o que se refletiu num notável déficit acumulado na balança de transações correntes. A dívida externa bruta de médio e de longo prazos aumentou 60\% e as reservas internacionais reduziram-se 66\% entre 1978 e 1982 (DELGADO, 2008).

Se adicionarmos a essa conjuntura o colapso do mercado internacional de crédito a partir de setembro de 1982, com a moratória mexicana, podemos ter uma dimensão da dramaticidade da crise externa no início dos anos 1980: acumularam-se déficits consideráveis na conta de transações correntes, ao mesmo tempo em que, a partir de 1982, os bancos internacionais recusaram-se a manter o fornecimento do montante de empréstimos requerido pelo seu financiamento. Como consequência, a economia brasileira foi obrigada, em um curtíssimo prazo, a ajustar-se unilateralmente a essa situação, ou seja, a pôr imediatamente em prática uma política econômica que viabilizasse a redução considerável do déficit em transações correntes, por meio da obtenção de grandes superávits na balança comercial.

Os resultados desse ajustamento doméstico à crise externa foram extremamente danosos para a economia brasileira, como o demonstram o pífio crescimento do PIB, a taxas médias anuais de 1,7\% na década de 1980, muito abaixo do que ocorreu na década de 1970 (taxa média de 8,7\% a.a.) e em todo o período do pós-guerra até 1979 (taxa média de 7\% a.a.), além da constante ameaça de hiperinflação, do colapso financeiro do Estado e da perda progressiva de sua capacidade de implementar políticas econômicas setoriais autônomas. Paradoxalmente, no entanto, o desempenho da agricultura foi mais favorável do que o do setor industrial e mesmo da economia como um todo, não obstante a grave crise ocorrida no mercado agrícola mundial no período 1980-84, caracterizada por uma substancial queda dos preços internacionais das commodities agrícolas.

Aparentemente, dois elementos foram particularmente importantes para explicar esse desempenho da agricultura. Em primeiro lugar, o governo Figueiredo estabeleceu, em 1979, uma prioridade à agricultura - que o então ministro Delfim Neto popularizou com o mote de "encher a panela do povo" -, em função da expectativa generalizada de uma crise de abastecimento de alimentos, devida ao 
fraco desempenho de sua produção na década anterior, o que se refletiu numa mudança da política agrícola em favor do fortalecimento da política de preços mínimos (indexando-os à inflação) e da diminuição da importância da política de crédito rural. Nesse sentido, o temor do desabastecimento interno de alimentos, numa conjuntura de crise da economia nacional, obrigou o governo militar a tomar medidas para favorecer o aumento de sua produção.

E, em segundo lugar, a política de desvalorização da taxa de câmbio foi capaz de compensar, em moeda nacional, as perdas de receitas em dólares dos exportadores brasileiros, devida à queda dos preços internacionais das commodities agrícolas, garantindo a continuidade de sua produção. A produção de soja, por exemplo, introduzida em grande escala na década de 1970, permaneceu aumentando, mas a taxas inferiores: sua produção deslocou-se progressivamente, do Sul para a região Centro-Oeste, onde passou a representar, no final da década, mais de $40 \%$ da produção brasileira.

Em suma, pode-se dizer que nos anos 1980 as políticas cambial, de preços mínimos e tecnológicas viabilizaram o crescimento agrícola em um ambiente macroeconômico interno e externo bastante desfavorável. Apesar da prioridade dada à consecução de grandes superávits na balança comercial, a composição da produção agrícola tornou-se menos desequilibrada, em relação à década anterior, em razão dos estímulos para a expansão da produção para o mercado interno e em função da crise do mercado agrícola mundial, na primeira metade dos anos 1980. As distorções provocadas pelo crédito rural na década de 1970 - principal estímulo ao processo de modernização da agricultura aí desencadeado - foram atenuadas (pela própria redução na disponibilidade de crédito), e a rentabilidade das culturas domésticas aumentou em relação às de exportação (considerada a relação dos índices de preços reais de ambas) (GOLDIN; REZENDE, 1993).

Com o melhor desempenho relativo dos produtos de alimentação, a década de 1980 foi mais favorável para a agricultura de mercado interno do que a década de 1970, o que aparentemente favoreceu a agricultura familiar, ou pelo menos alguns de seus setores.

É fundamental considerar, ademais, que no início dos anos 1980 aprofundase a crise de poder e de legitimidade da ditadura militar, a qual já se acumulava desde a segunda metade da década passada, culminando na redemocratização institucional do país em 1985, depois de 21 anos de ditadura, e na convocação de uma Assembleia Nacional Constituinte para, em 1987, elaborar uma nova Constituição, promulgada em 1988.

No ambiente de abertura política do final dos anos 1970 e início dos 1980, e no contexto da luta pela democratização do país, a questão agrária ganha nova 
relevância na discussão pública sobre os custos e benefícios das transformações recentes ocorridas no meio rural, de modo que a reforma agrária passa a assumir uma importância política central, como a reivindicação representativa e unificadora de diferentes demandas oriundas da diversidade de grupos e de atores sociais e de lutas existentes no meio rural'2.

Surgem novos personagens: os "atingidos por barragens" - sejam proprietários, posseiros, parceiros, arrendatários, expulsos de suas terras para a construção de grandes usinas hidrelétricas, ligadas aos grandes projetos de energia do II Plano Nacional de Desenvolvimento -, os "seringueiros" - resistindo na Região Norte à transformação dos seringais em pastagens -, os "pequenos produtores" - que perderam ou estavam perto de perder suas terras no Sul, em função da modernização, assumindo progressivamente a identidade de "semterra" -, além dos "posseiros" nas áreas de "fronteira agrícola" do Norte e do Centro-Oeste.

Aparecem também novas reivindicações: por políticas de preços e de crédito rural para pequenos agricultores tecnificados; por melhores preços e condições contratuais por agricultores integrados às agroindústrias (fumo, suínos, frango, uva), especialmente no sul do país. E ganham visibilidade e espaço público novos movimentos sociais rurais, como o MST, o Movimento dos Atingidos por Barragens, o movimento de mulheres trabalhadoras rurais, o Conselho Nacional dos Seringueiros e antigas e novas representações do movimento sindical, como a CONTAG e a CUT, além da presença de entidades da Igreja Católica, como a CPT, e de organizações não governamentais, como FASE, IBASE, CEDI, ABRA etc. que se envolveram na Campanha Nacional pela Reforma Agrária e pela mobilização da sociedade civil a favor da reforma agrária durante a Assembleia Constituinte.

Como consequência da gradual afirmação social desses novos personagens, atores e reivindicações, a questão agrária passou progressivamente a ganhar uma visibilidade política sem precedentes na história do país, tornando-se tematicamente mais complexa e diversificada e abrindo caminho para a futura implosão da identidade entre rural e agrícola e entre desenvolvimento e modernização - tão cara à ideologia e à política governamentais dominantes no período da ditadura militar -, que ganharia maior vigor e substância conceitual e política, a partir da década de 1990.

Esse processo foi energizado na década de 1980 pelo impulso e pela importância ganha, internacional e nacionalmente, pela crítica incisiva ao caráter excludente e aos nefastos efeitos ambientais, culturais, econômicos e sociais do

2 A discussão que se segue sobre questão agrária e reforma agrária está baseada em Medeiros (2002). 
processo de modernização agrícola da revolução verde implantado no Brasil e em outros países do então chamado Terceiro Mundo a partir da década de 1970.

No caso brasileiro, esta crítica foi encabeçada pelas associações de agrônomos e pelas ONG, e gradativamente assumida pelos movimentos sociais rurais, iniciando um processo de debate em torno das então chamadas "tecnologias alternativas", cuja politização e aprofundamento conceitual e técnico iria desembocar na convicção de que não bastava e era equivocado reivindicar a democratização da revolução verde, que a luta deveria centrar-se na construção e na implementação de um outro modelo de desenvolvimento rural, cujas consequências ambientais, sociais, econômicas, culturais e políticas fossem benéficas aos pequenos produtores e às populações rurais. Nesse sentido, a discussão internacional em torno de um "outro desenvolvimento", na década de 1970, e o avanço da preocupação planetária com a preservação do meio ambiente e com a concepção do que poderia ser um "desenvolvimento sustentável" para a humanidade, a partir dos anos 1980, representaram estímulos decisivos.

Um ponto alto da revitalização do debate sobre a reforma agrária como questão pública de interesse político, econômico e social na década de 1980 foi a elaboração da Proposta de Plano Nacional de Reforma Agrária (PNRA), apresentada como uma das prioridades do governo da chamada Nova República, que se seguiu ao término do regime militar (MEDEIROS, 2002).

O PNRA recebeu o apoio da CONTAG e a oposição do MST e da CUT, no campo dos atores favoráveis à reforma agrária. Enfrentou também uma forte oposição dos representantes das elites agrárias, que criaram uma nova organização, a UDR, com o objetivo precípuo de evitar a aprovação do plano, de ganhar espaço na mídia contra a reforma agrária, de combater as ocupações de terra lideradas pelo MST, e de influenciar a Assembleia Constituinte na defesa do direito de propriedade da terra e no bloqueio da criação de canais constitucionais capazes de viabilizar uma ampla reforma agrária.

O PNRA foi abandonado pelo governo Sarney e a articulação das elites agrárias no combate ao plano foi decisiva para impedir o avanço de propostas de reforma agrária mais consistentes e abrangentes na Constituinte e para dificultar tentativas futuras de implementá-las. As cisões que se estabeleceram na apreciação do Plano entre as representações da sociedade civil e dos agricultores favoráveis à reforma agrária também serão importantes para os rumos assumidos pela luta pela reforma agrária na década seguinte. Por fim, a experiência do PNRA escancarou as enormes dificuldades enfrentadas pela reforma agrária diante de uma burocracia estatal altamente centralizada e fragmentada, forjada durante o regime militar, e 
que se mostrava muito mais sensível aos interesses das elites agrárias do que dos trabalhadores rurais.

Como concluiu Bruno (2009, p. 107), de forma admiravelmente sintética e pertinente, num texto originalmente escrito em 2002, “(o) tempo do agronegócio, hoje, é tributário e herdeiro da vitória política da grande propriedade fundiária nos anos de 1980".

\section{A DÉCADA DE 1990. A “CONFLUÊNCIA PERVERSA” DE DOIS PROJETOS POLÍTICOS CONTRADITÓRIOS E SEUS REFLEXOS NO MEIO RURAL}

Com o aprofundamento da crise econômica, na década de 1980, que se manifestou através da aceleração inflacionária, do fracasso dos planos de estabilização, e da crise financeira do Estado, a capacidade e a disposição de intervenção do governo através de políticas públicas foi progressivamente minada, tanto operacional como ideologicamente, de modo que a política agrícola que havia sido posta em prática na década de 1980 foi inviabilizada quase integralmente no final do período.

Embora o Plano Cruzado tenha tido efeitos positivos sobre os investimentos e provocado uma euforia agrícola em 1986, o fracasso da sequência de planos de estabilização posteriores criou uma enorme instabilidade nas expectativas dos agentes econômicos e gerou comportamentos altamente especulativos quanto aos estoques e ativos agropecuários, intensificando o caráter especulativo da formação dos preços das commodities agrícolas, o que redundou, ajudado por outros fatores, numa crise agrícola, no início dos anos 1990.

O agravamento da crise financeira do Estado e o aumento das taxas de juros ocorridos no final da década de 1980 levaram ao colapso da política de preços mínimos executada no período, pois tornaram excessivamente caro e difícil de ser financiado o carregamento de estoques de produtos agrícolas (de alimentação e de exportação) realizado pelo governo. Ademais, a partir de 1988, sucedeu uma valorização da taxa de câmbio real, que se estendeu pela década de 1990, neutralizando outro instrumento de política econômica de significativa relevância para a agricultura nos anos 1980.

Simultaneamente, começou em 1987/88 o processo de desmonte da política pública de regulação do setor agrícola. Abriu-se, dessa forma, a porta para o abandono do sistema de política agrícola baseado na coordenação do mercado interno e na intervenção direta nos mercados agrícolas e para a adesão 
a uma estratégia de liberalização de mercados e de privatização de instrumentos de política, que veio a ser implementada ao longo da década de 1990 (governo Collor e primeiro governo Fernando Henrique Cardoso) - numa conjuntura de abundância de créditos internacionais para a economia brasileira - com efeitos negativos para a agricultura e, principalmente, para a agricultura familiar ${ }^{3}$.

A taxa de crescimento da economia foi bastante medíocre na década de 1990, apresentando taxas médias anuais de crescimento do PIB mais baixas, quando comparadas aos anos 1970 e 1980: 1,7\% a.a. para o PIB total, 0,8\% a.a. para o PIB industrial e 2,5\% a.a. para o PIB agrícola. Note-se que as décadas de 1980 e 1990 apresentaram um comportamento completamente diverso da tendência histórica apresentada pela economia brasileira em todo o pós-guerra, até o final dos anos 1970: um crescimento bastante medíocre da economia como um todo e uma relativa estagnação do crescimento industrial, com taxas médias anuais muito abaixo das da agricultura. O processo de globalização mundial e a adoção de políticas neoliberais de abertura comercial e de relativa desindustrialização parecem ter induzido um retorno do Brasil ao projeto de "vocação agroexportadora", defendido historicamente pelas elites agrárias e que vai redefinir, dessa perspectiva, o papel que a agricultura deve desempenhar na economia.

O comportamento da agricultura e, em particular, da agricultura familiar (para o mercado interno), nesta década foi influenciado fundamentalmente por três medidas distintas de política econômica. Em primeiro lugar, a liberalização comercial e o desmonte do modelo de intervenção do Estado, que prevaleceu na agricultura até a década de 1980. Isso significou, entre outras medidas: (i) a enorme redução do volume de recursos aplicados nas principais políticas agrícolas; (ii) a liquidação da política governamental de estoques públicos de alimentos, que foram reduzidos em 85\% em 5 anos; e (iii) a queda considerável das tarifas de

3 Um dos raros estudos que tentam fazer uma avaliação dos efeitos da política de liberalização comercial da década de 1990 sobre a agricultura familiar, e que serviu de base às nossas considerações, é Melo (2001). Neste trabalho, o autor leva em conta 22 produtos agropecuários (18 agrícolas e 4 animais), distribui esses produtos entre o que chama de agricultura patronal e agricultura familiar, e considera como produzidos pela agricultura familiar aqueles produtos para os quais a maior incidência de produção verifica-se em estabelecimentos com até 100 ha de área total (de acordo com a classificação do Censo Agropecuário de 1995/96). Os produtos contemplados como da agricultura familiar são: amendoim, batata, cebola, feijão, fumo, mandioca, sisal, tomate, uva, suínos, frango e leite. Os da agricultura patronal são: algodão, arroz, cacau, café, cana-de-açúcar, laranja, milho, soja, trigo e bovinos. Dessa forma, no estudo de Melo (2001), a agricultura familiar é identificada fundamentalmente com a agricultura para o mercado interno, essencialmente produtora de alimentos (com a grande exceção do fumo). Embora seja uma simplificação, pois há produtos de exportação que são também produzidos por agricultores familiares (como a soja, por exemplo), essa identificação não é incorreta e permite uma aceitável aproximação do objeto que pretende estudar.

4 Ver a respeito, Delgado (1994) e Delgado e Fernandes Filho (1998). 
importação de produtos alimentares e do algodão (a diminuição das tarifas de importação no período $1989 / 97$ foi de 35\% para o arroz, 48\% para o feijão, 53\% para o leite, $71 \%$ para o algodão $48 \%$ para o trigo etc.).

Em segundo lugar, a adoção do Plano Real, em 1994, que levou a uma queda da renda real do setor agrícola de cerca de 20 a 30\% no primeiro semestre de 1995, que teve como consequências adicionais: (i) o enorme aumento dos custos financeiros dos agricultores (devido à elevação das taxas de juros e à escassez de crédito), e (ii) um impacto depressivo direto e significativo na formação de preços dos principais produtos agrícolas.

E, em terceiro lugar, a considerável valorização da taxa de câmbio até 1998, associada ao grande volume de recursos disponíveis no sistema financeiro internacional e a taxas de juros domésticas bastante elevadas, três componentes fundamentais da implementação do programa de estabilização do real (a nova moeda adotada em 1994) e que contribuíram para explicar seu sucesso. A consequência adicional sobre a agricultura foi o grande incentivo ao aumento das importações - que se tornaram, ademais, um grande negócio financeiro, em função do diferencial de custos entre os empréstimos externos e internos - e o correspondente desestímulo às exportações. O valor total das importações agrícolas passou da média de US\$3,4 bilhões em 1990/91, para US\$ 7,1 bilhões em 1994/95 e US\$6,9 bilhões em 1996/97 (SOARES; ROMANO; DELGADO, 2004, p. 12), uma situação sem precedentes na história moderna da economia brasileira.

Dois outros efeitos da política de liberalização comercial sobre a agricultura devem ser mencionados (MELO, 2001). O primeiro é que a evolução dos preços reais recebidos pelos agricultores foi extremamente desfavorável, ao longo da década de 1990, sendo que a maior penalização recaiu sobre os agricultores familiares, cujos produtos apresentaram uma taxa média anual de redução de preços reais quase o dobro da dos preços reais dos produtos da agricultura patronal, nos termos definidos por Melo (2001).

Isso explica o fato de que a produção total de feijão, de arroz e de mandioca tenha permanecido praticamente estagnada na década, enquanto a produção de trigo reduziu-se de uma média bianual de 6 milhões de t em 1987/88, para 1,8 milhões em 1994/95 e para 2,3 milhões de t em 1998/99, o que repôs a dependência do consumo interno de trigo das importações. Segundo Melo (2001), no caso da agricultura patronal, os efeitos deletérios da política macroeconômica foram parcialmente compensados pelo comportamento favorável dos preços internacionais de alguns produtos (como soja, açúcar, suco de laranja e café). No caso da agricultura familiar, esses resultados negativos foram amplificados pela 
relativa estagnação do mercado interno para seus produtos, consequência do baixo crescimento da economia e do emprego urbano.

Esse desastroso "ajuste ultraliberal" fomentado pelo primeiro governo FHC - que além dos efeitos maléficos sobre a agricultura, como vimos, promoveu a privatização de parte do setor produtivo estatal e aumentou o endividamento externo - entrou em colapso com a crise de liquidez internacional ocorrida no final de 1998, a qual afetou pesadamente a economia brasileira, provocando fuga de capitais e exigindo uma nova mudança na política cambial e na política de ajustamento externo. A política econômica do segundo governo FHC, à semelhança do que ocorreu na década de 1980, voltou, então, a enfatizar a estratégia de geração de grandes e crescentes saldos na balança comercial, para enfrentar a deterioração da conta de transações correntes do balanço de pagamentos, decorrente da política de endividamento externo priorizada no primeiro governo.

Da mesma forma como na década de 1980, os setores agroexportadores foram estimulados a desempenhar esse papel e o autodenominado agronegócio passou a ser prioridade da política econômica doméstica. Nesse sentido, como diz Delgado (2005), ocorre um verdadeiro "relançamento" do agronegócio, a partir de 1999, alavancado por algumas medidas importantes de política: (1) um programa prioritário de investimentos em infraestrutura territorial (os "eixos territoriais de desenvolvimento"), visando à incorporação de novos espaços territoriais, meios de transporte e corredores comerciais ao agronegócio (por exemplo, nas regiões Centro-Oeste e Norte do país); (2) a reorganização da Empresa Brasileira de Pesquisa Agropecuária (Embrapa) para operar o sistema público de pesquisa, em maior consonância com as empresas multinacionais (como exemplifica o caso dos transgênicos); (3) a "frouxidão da política fundiária", ou seja, sua relativa incapacidade de fiscalizar e regular o mercado de terras, deixando fora do controle público as "terras devolutas"; e (4) a desvalorização da taxa de câmbio real, de modo a tornar o agronegócio novamente competitivo no comércio internacional.

Associado a uma conjuntura favorável de preços no mercado internacional, especialmente para a soja, o "relançamento" do agronegócio levou a um crescimento do PIB agrícola de 4,6\% a.a., em média, no período 2000-2003, bem acima das taxas médias anuais do PIB total e do PIB industrial, de 1,8\% e 1,5\%, respectivamente. Nesse contexto, a produção de soja cresceu de modo impressionante atingindo 38 milhões de t em 2001, 42 milhões em 2002 e 52 milhões em 2003, de tal forma que soja e milho passaram a representar $80 \%$ do total da produção de grãos no país em 2003 (SOARES; ROMANO; DELGADO, 2004, p. 8) . $^{6}$

Como o chamou Delgado (2005).

6 Este processo foi acompanhado por um forte movimento de fusões e de aquisições de empresas 
As exportações agropecuárias brasileiras também aumentaram de forma expressiva neste período (quase 50\%), passando de US\$20,6 bilhões em 2000 para US\$ 30,6 bilhões em 2003. Ademais, nesse último ano, União Europeia (36\%), Ásia (18\%) e Estados Unidos e Canadá (17\%) foram destinatários de 71\% do total dessas exportações. O crescimento da participação da Ásia - que no início da década de 1990 era de 10\% - foi talvez uma das mais importantes características da evolução da pauta de exportações agrícolas no período 2000-2003 e deveu-se basicamente ao enorme crescimento, desde então, das exportações do complexo soja para a China. Neste sentido, é possível dizer que o Brasil conquistou uma condição de grande comercializador mundial de produtos agroalimentares nesse período, mas que ela foi acompanhada, como vimos acima, por um processo crescente de monoculturização da produção de grãos e de dependência exagerada da pauta de exportações agrícolas do complexo soja (SOARES; ROMANO; DELGADO, 2004, p. 9-10).

Do ponto de vista político e das perspectivas futuras do meio rural brasileiro, é importante assinalar que a década de 1990 foi um período crucial, tanto para a continuidade do padrão dominante de relações economia-meio rural no Brasil, quanto para a progressiva elaboração de uma visão alternativa acerca do significado do rural e do desenvolvimento rural e para a democratização das relações sociais e políticas no campo.

Esta observação é indissociável, em nosso entender, da ocorrência na sociedade brasileira, a partir deste período, do que Dagnino (2004) chamou, apropriadamente, de uma "confluência perversa" entre dois projetos políticos contraditórios e em disputa, cuja ocorrência simultânea se deveu a fatores bastante diversos.

Por um lado, o projeto político neoliberal, que se originou (e foi expressão) da restauração conservadora mundial liderada pelos Estados Unidos, desde o início dos anos 1980, tendo em vista a retomada de sua hegemonia econômica, política e militar, que pareceu ameaçada, para suas elites, pelos acontecimentos ocorridos, em várias dimensões, na década de 1970.

No caso brasileiro, a política macroeconômica norte-americana desencadeou, no início dos anos 1980, como vimos, a crise da dívida externa, obrigando o país a um ajustamento econômico unilateral, que desestruturou a economia e fragilizou inteiramente a capacidade do Estado formular políticas públicas ativas. Trata-se do

no setor agroindustrial de esmagamento de soja, provocando concentração econômica e desnacionalização do setor: a participação do capital internacional no capital total investido elevou-se consideravelmente, passando de 16\% em 1995 para 57\% em 2005 (HEREDIA; PALMEIRA; LEITE, 2009, p. 11-12). As mudanças mais intensas ocorreram no período 19952000. Ver também Benetti (2004). 
que Delgado (2005) chamou de "ajustamento constrangido à ordem econômica globalizada".

Essa situação, que acompanhou a capitulação das elites diante da ideologia da globalização, abriu caminho para a hegemonia do projeto neoliberal nos dois governos Fernando Henrique Cardoso, portadores da proposta (1) de privatização do setor produtivo estatal e de redução do protagonismo do Estado no crescimento econômico; (2) de ênfase no papel ativo das empresas internacionais em mercados domésticos desregulados e liberalizados, através da abertura comercial; e (3) do papel estratégico das exportações agrícolas, para enfrentar o estrangulamento recorrente da balança de pagamentos e para alavancar a retomada do crescimento econômico, especialmente em uma economia que se estava tornando mais aberta e desregulada.

Por outro lado, desenvolvia-se o que se pode chamar de projeto político democratizante, que teve sua origem na retomada da luta pela democratização do país, desde o final dos anos 1970, e que ganhou força com a democratização institucional em 1985 - apesar da frustração da derrota das "diretas já" - e com a nova Constituição Federal de 1988. Na perspectiva dos atores do projeto democratizante - partidos políticos, movimentos e organizações da sociedade civil - a retomada da política e a reconstrução da democracia não deveriam ficar restritas à (embora indispensável) reativação/redefinição das instituições democráticas tradicionais, como partidos, parlamento, judiciário, eleições livres etc. Tratava-se de democratizar não apenas o aparato formal do Estado, mas a sociedade, e de implementar processos de descentralização das atividades governamentais e da relação entre Estado e sociedade, capazes de implodir não o Estado como tal, mas o Estado autoritário, privatizado e centralizado, herdado da ditadura militar.

Neste sentido, os atores do projeto democratizante reivindicavam o alargamento das noções de democracia - avançando para a ideia de democracia participativa e não apenas representativa - e de público - que não deveria ficar restrito apenas ao que o Estado define como tal - incorporando a proposta de criação de novos espaços públicos de participação que, ao viabilizarem a inclusão de novos atores sociais (tanto urbanos como rurais) e o surgimento de novas práticas de interlocução entre o Estado e a sociedade, vitalizariam a tentativa de viver a transição democrática como um processo de democratização de uma sociedade autoritária e excludente, no sentido de transformação da cultura política predominante e de uma maior compatibilização entre esfera pública e sistema político, como requisitos necessários ao fortalecimento da governança democrática no país. 
A Constituição de 1988 foi, neste aspecto, uma conquista fundamental, pois viabilizou a criação de esferas públicas de participação - concebidas não como instituições estatais, mas sim como instituições públicas, das quais fazem parte representantes do Estado e da sociedade civil - cujos objetivos primários são o avanço da democratização relativa ao controle social e à descentralização de várias políticas públicas setoriais. Assim, surgiram os diversos conselhos municipais e estaduais, tanto urbanos quanto rurais, além de alguns conselhos nacionais, como o Conselho Nacional de Segurança Alimentar e Nutricional (CONSEA).

Note-se, além disso, que a prática das conferências nacionais, estaduais e municipais foi fortalecida a partir da década de 1990, até chegar a seu auge no governo Lula, como um instrumento indispensável de aprendizado e de mobilização em torno da construção de agendas de reivindicações da sociedade civil, com vistas a influenciar a formulação e a implementação de políticas públicas setoriais (saúde, educação, meio ambiente, cidades, desenvolvimento rural etc.).

Uma das manifestações fundamentais do projeto neoliberal em relação ao rural e à agricultura, em particular, foi o incentivo, através de políticas públicas e de outras benesses governamentais, ao aumento da produção para a exportação, de modo a viabilizar a obtenção continua de superávits crescentes na balança comercial, tendo em vista a exigência de gerir a conta de transações correntes do balanço de pagamentos do país, tornada uma questão prioritária de política, a partir da década de 1980, devido aos desequilíbrios provocados pelo endividamento externo, pela abertura progressiva da economia à globalização, pela instabilidade conjuntural característica da liberdade de movimento dos capitais internacionais pós-anos 1980, e pelo comportamento dos preços internacionais das commodities agrícolas.

Assim sendo, a estratégia de ajustamento externo do projeto neoliberal aprofundou consideravelmente a especialização da agricultura brasileira na produção para exportação, o que transformou o chamado agronegócio - em especial nos complexos de milho e soja, cana-de-açúcar, papel e celulose, e pecuária bovina - no principal protagonista e no grande beneficiário deste projeto no meio rural $^{7}$. A intensa complementaridade estrutural entre expansão do agronegócio e

O conceito de agronegócio que estamos utilizando não é o de agroindústria, nem o de cadeia produtiva. Estamos considerando, neste texto, o agronegócio no Brasil, como um bloco econômico e de poder bastante amplo e internacionalizado, relacionado a diversas atividades agrícolas, agrárias e agroindustriais domésticas, e que inclui produtores e empresários capitalistas, latifundiários, e setores industriais e financeiros nacionais e estrangeiros. O caráter macro do texto justifica o tratamento do agronegócio como um bloco monolítico, da mesma forma que, em abordagens semelhantes, se fala, por exemplo, do Estado, da sociedade civil e do mercado como um agregado. Qualquer análise concreta da economia, da sociedade e da política do agronegócio exige, no entanto, o rompimento deste monolitismo, em favor 
“ajustamento constrangido à globalização" passou, a partir do final dos 1990, a representar o principal papel a ser desempenhado pela agricultura na economia, segundo o projeto neoliberal. Essa opção de política deu ao agronegócio um caráter de "imprescindibilidade", fortalecendo sua projeção e peso políticos diante do Estado e da sociedade, e aumentando sua presença política e sua exposição favorável na mídia. Tornou-se, então, portador da proposta dominante de desenvolvimento para a agricultura brasileira que, em sua essência, tenta atualizar, para os tempos e para a ideologia da globalização, o tradicional modelo de modernização da agricultura, concentrador, excludente e destruidor do meio ambiente, predominante desde a década de 1970.

Do lado do mundo do trabalho no meio rural, as profundas transformações ocorridas nas décadas de 1970 e 1980 - não apenas nas relações econômicas e sociais, mas na própria reflexão sobre o significado da modernização agrícola e da multidimensionalidade de seus efeitos - provocaram uma significativa diferenciação das categorias sociais existentes, que passaram a reivindicar identidades próprias e a se constituir como atores políticos diversificados no cenário nacional. Com isso, "ocorreu uma "implosão" da categoria "trabalhador rural”, tal como constituída nos anos 1970, acompanhada pela emergência de diversas possibilidades organizativas que romperam com a tradição unitária de representação do sindicalismo rural"». As alternativas que surgiram, dentro e fora do universo sindical, tenderam a contestar o monopólio da CONTAG na representação dos trabalhadores rurais no campo, assim como introduziram novos temas e novas demandas em sua pauta de reivindicações.

Das novas identidades surgidas, três ganharam uma considerável importância política ao longo dos anos 1990, os "sem-terra", os “assentados" e os "agricultores familiares", em função da intensidade e abrangência das tensões e das lutas sociais existentes, do avanço da crítica, intelectual e política, ao modelo dominante de modernização, e da consciência crescente de que o fortalecimento desses movimentos sociais e o atendimento das demandas de seus representados exigiam entrar pesadamente na disputa pelos recursos públicos administrados pelo Estado através das políticas públicas. Ou seja, de que os movimentos sociais rurais deveriam encarar a luta por seu reconhecimento pelo Estado, e não mais colocarse "de costas" para ele, o que significava lutar pela conquista de políticas públicas diferenciadas e adequadas às demandas das categorias sociais que representavam,

da análise da diversidade, heterogeneidade e especificidade de seus componentes e de suas relações com o Estado e a sociedade, em distintas territorialidades.

8 Medeiros (2001, p. 109). No que segue, faremos livre uso deste excelente ensaio sobre os conflitos sociais e as formas de organização dos trabalhadores rurais brasileiros no período que estamos considerando. 
e que, além disso, seriam indispensáveis para o aprendizado concreto e cotidiano da construção de um modelo de desenvolvimento rural alternativo.

Nesse sentido, os sem-terra e os assentados são as identidades sociais que se forjaram mais diretamente na reivindicação pela reforma agrária, entendida aqui como uma transformação política, econômica e social indispensável para a democratização do campo e para a mudança do padrão de modernização predominante. Principalmente através do protagonismo do MST, mas não apenas, a identidade de sem-terra e de assentados espalhou-se progressivamente por todo o país, superando sua base sulista inicial, transformando os assentamentos de reforma agrária, apesar de sua fragilidade, em "espaços de produção, sociabilidade e intervenção política”, como diz Medeiros (2001, p. 114), e promovendo mobilizações de caráter nacional, como a "marcha dos sem-terra" a Brasília em 1997, que obrigaram a mídia a dar-lhes visibilidade pública e ao governo FHC, no final dos anos 1990, a responder com algumas ações políticas tentando assumir uma maior iniciativa no debate sobre a reforma agrária9.

A outra identidade social rural importante que surge na década de 1990 é a de "agricultores familiares", que vem substituir a de "pequenos produtores", dominante nos anos 1980. Algumas razões para isso são (MEDEIROS, 2001): (1) a perda de relevância política dos assalariados rurais; (2) a maior complexidade social e política dos pequenos agricultores, tanto em termos de suas demandas e mobilizações, como de suas lideranças, que passam a ganhar maior peso no sindicalismo em todo o país, através principalmente das chamadas "oposições sindicais"; (3) a progressiva decepção com a modernização da agricultura e sua incapacidade de atender às demandas desses agricultores, bem como o surgimento de várias "questões" correlatas, como a das tecnologias alternativas, da organização produtiva, da comercialização, da agroindustrialização, do meio ambiente etc., o que acelerou a percepção em torno da necessidade de um novo modelo de desenvolvimento; e (4) a intensificação da reflexão intelectual e do debate sobre a permanência, o significado e a importância econômica e social da agricultura familiar para um desenvolvimento rural mais democrático e inclusivo, tomando principalmente como referência o conhecimento da experiência europeia, que muitas assessorias e lideranças sindicais passaram a ter acesso através de intercâmbios promovidos pela Igreja e por diversas ONG.

Como resultado, a categoria agricultor familiar passou a ser colocada no centro da discussão sobre políticas públicas para o campo, trazendo nova

9 Essa mobilização do governo FHC foi também impulsionada pelo repúdio nacional e internacional aos massacres de sem-terras em Corumbiara (agosto de 1995) e Eldorado de Carajás (abril de 1996). Como consequência, o governo FHC criou, inclusive, o cargo de Ministro Extraordinário de Políticas Fundiárias. 
valorização e dando novos significados a temas relativos à produção, escolha de técnicas, comercialização, agroindustrialização, preços e crédito, associativismo, meio ambiente etc., além do tema comum da reforma agrária, de modo que, a partir de então, ganha relevância e urgência política, especialmente para o movimento sindical, a proposta de construção de um "projeto alternativo de desenvolvimento rural com base na agricultura familiar", que, pela primeira vez em todo o país, afirma a possibilidade de um projeto alternativo (à modernização conservadora e ao agronegócio) de desenvolvimento fundado na agricultura familiar ${ }^{10}$.

A generalização dessa identidade e dessa proposta de projeto por todo o país, deixando de ser uma questão meramente sulista (como aconteceu, analogamente, com as categorias de sem-terra e de assentado), foi impulsionada por vários fatores, entre os quais: (i) as transformações socioeconômicas do meio rural que se espalharam progressivamente por todo o país, (ii) as grandes mobilizações nacionais, como os "Gritos da Terra", realizadas para influenciar o Estado e as políticas públicas e para ganhar visibilidade e apoio da sociedade, (iii) o surgimento de um sindicalismo identificado essencialmente com a agricultura familiar, como é o caso, por exemplo, da FETRAF, e (iv) o redescobrimento do espaço local, inicialmente o município - em função do processo de descentralização das políticas públicas consagrado pela Constituição de 1988 e das esferas públicas de participação municipais criadas para controlar socialmente sua gestão e execução -, estimulou/obrigou os sindicatos e as diversas associações de agricultores familiares a complexificarem sua forma de atuação na política municipal e a perceberem com mais clareza as demandas e os interesses dos agricultores, para influenciarem o processo de descentralização das políticas públicas em várias áreas (saúde, educação, desenvolvimento rural, gênero, geração etc.).

Em função do processo acima descrito, nossa hipótese neste ensaio é que os movimentos pela reforma agrária e pela construção de um modelo alternativo de desenvolvimento rural baseado na agricultura familiar, e o surgimento das identidades rurais de sem-terra, assentado e agricultor familiar, vão representar na década de 1990 os portadores politicamente mais importantes do projeto democratizante no meio rural brasileiro, e que vão disputar com o agronegócio o reconhecimento do Estado como interlocutores privilegiados no debate em torno das políticas públicas para o meio rural e a hegemonia na construção de propostas de desenvolvimento para o campo. Apesar da indiscutível força política do agronegócio, o projeto democratizante no meio rural não deve ser subestimado, inclusive em sua capacidade de influenciar progressivamente as políticas públicas,

10 A referência a esta proposta aparece explicitamente no Projeto CUT/CONTAG, Desenvolvimento e sindicalismo rural no Brasil, de 1998 (MEDEIROS, 2001, p. 116). 
como o demonstram, por exemplo, a criação do PRONAF em 1996, uma conquista decisiva para o reconhecimento da importância nacional dos agricultores familiares, e a implementação, a partir de 1992, do sistema de Previdência Social Rural, universalizando direitos sociais previstos na Constituição de 1988, com grande impacto social e econômico entre os agricultores familiares.

Assim, herdamos da década de 1990 uma disputa por propostas de desenvolvimento, políticas públicas e significados entre dois projetos políticos alternativos, o projeto neoliberal do agronegócio, pautado fundamentalmente pela expansão da agricultura de exportação estruturalmente complementar ao "ajustamento constrangido à globalização", e o projeto democratizante, representado inicialmente no meio rural pela proposta de reforma agrária e de desenvolvimento rural fundado na agricultura familiar, mas que deverá incorporar posteriormente novos atores e propostas, e que é pautado, entre outros elementos, pela afirmação da expansão da agricultura de mercado interno, do reconhecimento dos direitos sociais das populações rurais, da democratização do acesso às políticas públicas, e do objetivo fundamental da segurança alimentar e nutricional da população brasileira.

Não se trata, obviamente, de dois projetos estanques, que não se relacionam. Pelo contrário, seus relacionamentos são inúmeros, e o comportamento de um influencia as possibilidades e as características que vão ser assumidas pelo outro. Por exemplo, faz parte do projeto democratizante a reivindicação por formas de regulação pública da atuação do agronegócio e por maior transparência em seu relacionamento com o Estado. Há também possibilidades de complementaridades e de alianças entre atores de cada um dos projetos em situações específicas. Mas, de modo geral, a relação entre os dois projetos é uma relação conflitiva, a qual se manifesta em diversos aspectos, dentre os quais: (1) as propostas de desenvolvimento rural de que são portadores, (2) as fontes de crescimento de que dependem: do crescimento do mercado interno num caso, da contínua abertura de mercados externos em outro, e (3) os padrões e os instrumentos de política pública que privilegiam e reivindicam.

\section{O GOVERNO LULA: OPORTUNIDADES ABERTAS PARA O PROJETO DEMOCRATIZANTE E CONTINUIDADES DO PROJETO NEOLIBERAL}

A eleição de Luis Inácio Lula da Silva presidente do país, em 2003, foi uma clara conquista do projeto político democratizante: tratava-se de um sindicalista 
dos anos 1980, fundador e candidato histórico do Partido dos Trabalhadores (PT), apoiado pelos movimentos sociais urbanos e rurais, todos atores relevantes desse projeto. No entanto, o governo que tomou posse foi um governo de coalisão com alguns setores conservadores, tanto na composição ministerial como na bancada de apoio no Congresso, e que, além dos compromissos de campanha assumidos na Carta ao Povo Brasileiro, manteve uma política macroeconômica não muito distante, com exceções importantes (como o reforço do papel do Estado na economia, um maior controle da abertura externa, a revalorização das empresas estatais e a recusa em dar continuidade às privatizações) ao receituário neoliberal dominante.

Como não poderia deixar de acontecer, o governo Lula também se viu envolvido com a necessidade de fazer frente aos dois projetos políticos que temos enfatizado. Tentaremos, então, sugerir neste item, a existência de algumas atitudes e políticas do governo que constituem claras e importantes janelas de oportunidade para o avanço do projeto democratizante no meio rural e a presença de outras atitudes e políticas que representam continuidades do governo com o projeto neoliberal, em especial no apoio ao agronegócio e na manutenção de seu papel estratégico para o ajuste externo da economia brasileira. Essa tentativa de criar oportunidades para avançar o projeto democratizante, sem promover rupturas significativas com o projeto neoliberal, parece ser uma das características da complexidade do governo Lula, cujos resultados políticos só poderão ser plenamente avaliados no futuro.

Comecemos com a consideração de algumas políticas públicas desenvolvidas nos dois períodos do governo Lula que representaram apoios dirigidos diretamente à agricultura familiar, de forma principal, e a outras populações e povos existentes no meio rural no Brasil.

Em primeiro lugar, convém destacar que, durante o período 2003-início de 2010, houve um avanço na institucionalização dos mecanismos de política direcionados aos setores tradicionalmente mais marginalizados no meio rural brasileiro. Isso se refletiu na constituição de marcos legais importantes como, por exemplo, a Lei da Agricultura Familiar (Lei 11.326, de 24 de julho de 2006), a Lei Orgânica de Segurança Alimentar e Nutricional (Lei 11.346, de 15 de setembro de 2006) e, recentemente, a Lei de Assistência Técnica e Extensão Rural (ATER) (Lei 12.188, de 11 de janeiro de 2010), além da promulgação da Política Nacional de Desenvolvimento Sustentável dos Povos e Comunidades Tradicionais, pelo Decreto 6.040, de 07 de fevereiro de 2007. 
Em segundo lugar, o governo Lula montou um aparato governamental mais consistente e abrangente de apoio à agricultura familiar e a outras populações e povos habitantes do meio rural. Apesar das dificuldades e fraquezas ainda existentes, e da disparidade de poder em relação ao Ministério da Agricultura, Pecuária e Abastecimento (MAPA), o Ministério do Desenvolvimento Agrário (MDA) passou a assumir uma condição de ministério que trata das questões e dos temas relativos ao fortalecimento e à consolidação da agricultura familiar no país, bem como ao reconhecimento do direito ao acesso a políticas públicas e à reprodução econômica e social sustentável da diversidade de populações e de povos existentes no meio rural, muitos deles condenados anteriormente à "invisibilidade" 11 .

Isso faz grande diferença, porque significa, de alguma forma, o reconhecimento explícito da existência de outro tipo de agricultura no país, além do agronegócio, e que essa agricultura tem abrangência nacional, é bastante diversificada, e deve ser fortalecida, dada a admissão de sua importância para a produção (especialmente para o abastecimento alimentar doméstico), a geração de empregos e a defesa do meio ambiente. Significa também o reconhecimento da enorme diversidade cultural, econômica e social do rural brasileiro que abriga um amplo conjunto de populações e de povos, cuja saída da "invisibilidade", através da conquista de direitos sociais universais e de políticas públicas diferenciadas, é uma das atribuições primordiais de um Estado democrático.

A seguir, vamos apresentar algumas características assumidas por políticas e medidas específicas direcionadas a esses setores produtivos e populações rurais no governo Lula.

\subsection{O PLANO SAFRA PARA A AGRICULTURA FAMILIAR E O PROGRAMA NACIONAL DE FORTALECIMENTO DA AGRICULTURA FAMILIAR (PRONAF)}

Iniciado durante o primeiro governo Lula, o Plano Safra para a Agricultura Familiar foi uma significativa medida de política pública para estimular a agricultura

11 Com efeito, além dos agricultores familiares, os assentados da reforma agrária, extrativistas, ribeirinhos, quilombolas, indígenas, pescadores artesanais e aquicultores, seringueiros, povos da floresta e outros públicos passaram a ser considerados beneficiários das políticas e dos programas do MDA. 
familiar no país, cuja criação representou um esforço de ação conjunta entre atores da sociedade civil e agências governamentais articulados através do Conselho Nacional de Segurança Alimentar e Nutricional (CONSEA). Um de seus resultados fundamentais foi estimular, a partir do ano agrícola 2003/2004, o considerável aumento dos recursos financeiros à disposição da agricultura familiar através do PRONAF (Quadro 1) e da possibilidade de acesso simultâneo a outros programas de financiamento. No contexto do Plano Safra, o governo procurou consolidar também o processo de adaptação do PRONAF a novas demandas oriundas do reconhecimento da diversidade existente na agricultura familiar brasileira, por meio da criação de novas linhas de financiamento ou do fortalecimento das já existentes: PRONAF jovem, mulher, agroindústria, floresta, agroecologia, ECO, semiárido, pesca etc. E incentivou o aumento dos tetos e dos limites de enquadramento e a redução de juros e simplificação de garantias para financiamento a diferentes grupos de agricultores familiares, classificados inicialmente em grupos A, A/C, B, C, D e E (segundo seus níveis de renda e outros critérios), além da inclusão de outros públicos rurais, não propriamente de agricultores, como pescadores artesanais, extrativistas, quilombolas e outras.

Outro instrumento de política desenvolvido no contexto dos Planos Safra foi o Seguro da Agricultura Familiar (composto pelo Proagro, PRONAF Mais e Seguro-Safra), que se aliou às políticas de crédito, garantia de preços e comercialização, como componentes de uma estratégia para o fortalecimento da agricultura familiar durante o período 2003-2009.

Assim, os Planos Safras estabeleceram, a partir do ano agrícola 2003-2004, o apoio à comercialização e à segurança alimentar e, animaram, consequentemente, o progressivo aperfeiçoamento e o aumento da dotação de recursos do Programa de Aquisição de Alimentos (PAA), que iniciou como uma das linhas estruturantes das ações do Programa Fome Zero, promovendo tanto o incentivo à produção de alimentos básicos como a canalização dessa produção para as políticas sociais e emergenciais do governo, em suas três instâncias federativas. Ademais à política de comercialização foi incorporada uma Política de Garantia de Preços Mínimos (PGPM) e de Empréstimos do Governo Federal (EGF) para a agricultura familiar. Associam-se, por fim, às atividades compreendidas nos Planos Safras as políticas de assistência técnica e extensão rural, o apoio ao cooperativismo, medidas emergenciais de diversas ordens, e a prorrogação de dívidas dos agricultores familiares. 
Gráfico 1: Volume total de recursos executados pelo PRONAF (R\$), 1996-2008.

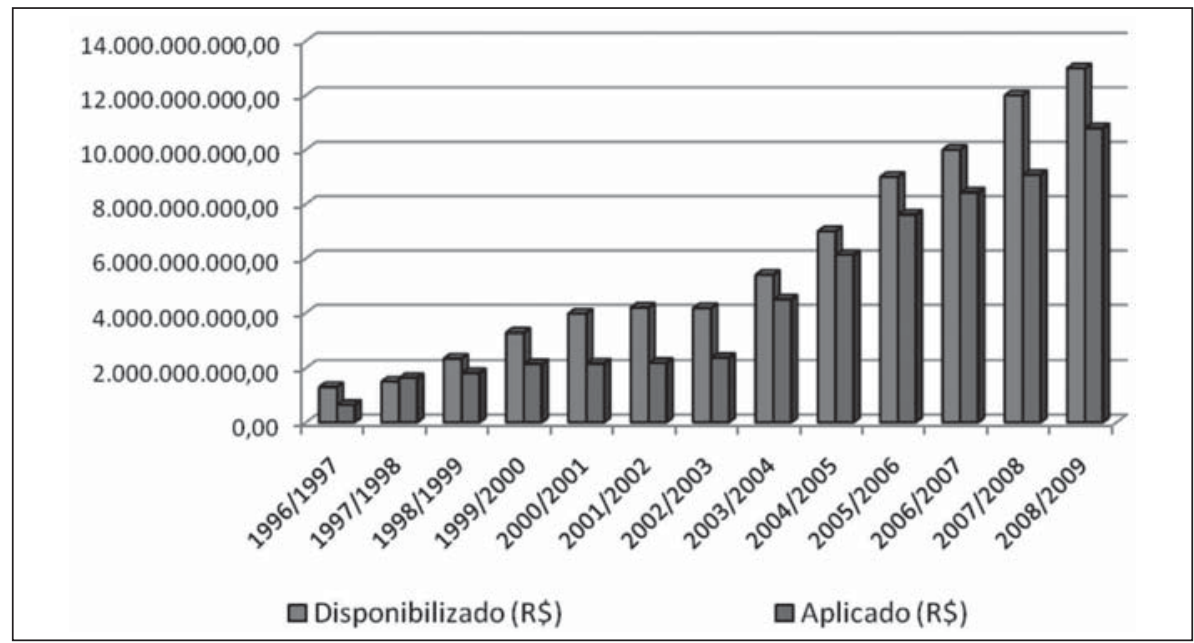

Fonte: PRONAF.

O Gráfico 1 permite visualizar o crescimento notável do volume de recursos aplicados pelo governo Lula para o PRONAF durante seus dois mandatos. Os recursos totais passaram de $\mathrm{R} \$ 2,3$ bilhões na safra 2002/2003 para $\mathrm{R} \$ 10,7$ bilhões na 2008/2009, o que representa um incremento de 454\% no volume de recursos investidos pelo programa no período ${ }^{12}$. O número total de contratos realizados no país também aumentou, mas numa proporção inferior $(53 \%)$ - passando de 953 mil em 2002 para 1,5 milhão em 2008 - embora tenha caído a partir de 2006. Com isso, o valor médio dos contratos do PRONAF que se manteve relativamente inalterado nos três primeiros anos do primeiro mandato (ainda que superior ao do governo FHC), começou a crescer significativamente em 2006, atingindo em 2008 um valor $74 \%$ superior ao de 2005 .

Note-se que no segundo governo FHC, a diferença entre recursos disponíveis e executados pelo PRONAF foi de 57\%, indicando que mais de $40 \%$ dos valores reservados acabaram não sendo aplicados. No governo Lula, além do aumento dos recursos disponíveis, houve uma expansão do volume aplicado, tendo a taxa de execução dos recursos alcançado uma média de 83\% entre 2003/04 e 2008/09, não ficando nunca abaixo de 75\%.

Este cenário se deve a um conjunto de condicionalidades, entre as quais se destacam: 1) a flexibilização das condições financeiras (redução da taxa de juros, expansão da carência, aumento do limite de recursos por contrato etc.);

12 Apesar deste feito, os recursos do PRONAF representavam, em média, apenas 14\% do total de recursos financeiros registrados pelo Sistema Nacional de Crédito Rural (SNCR) no período 2005-2009 (era de 10\% em 2003). 
2) a ampliação dos beneficiários (mulheres, jovens, ribeirinhos, extrativistas, indígenas, quilombolas, pescadores artesanais, agricultores com maiores rendas, grandes cooperativas etc.); 3) a diversificação das atividades econômicas apoiadas (PRONAF Agroindústria, Turismo Rural, Floresta, Agroecologia e ECO Sustentabilidade Ambiental); 4) o aumento dos municípios abrangidos (que passam de 80\% em 2003 para 97\% em 2008); e 5) a simplificação das condições de acesso (redução de alguns entraves bancários, maior facilidade de obtenção da Declaração de Aptidão, eliminação da classificação dos agricultores familiares por grupos etc.).

Durante todo o período que compreende as safras agrícolas de 2002/2003 a 2008/2009, cerca de 60\% dos recursos totais do PRONAF foram destinados, em média, ao crédito de custeio das safras e aproximadamente $40 \%$ foi alocado, em média, para crédito de investimento. Se, considerarmos a distribuição dos recursos para custeio agrícola entre os cultivos, verificamos que os cultivos alimentares ${ }^{13}$ receberam mais de $52 \%$ do montante para custeio agrícola em todo o período 2002-2009, com variações anuais para cima deste valor (por exemplo, em 2003 chegou a atingir $72 \%$ do total), embora tenha caído para 48\% em 2009, numa tendência de redução que se inicia em 2007. O grande destaque entre os cultivos alimentares é o milho, cuja participação no custeio agrícola é a mais importante, tendo oscilado entre 48\% e 32\% (em 2009) do total do custeio agrícola no período. A participação dos cultivos de exportação ${ }^{14}$ oscilou em torno de $30 \%$ em todo o período, com realce para soja e café. Entretanto, a partir de 2007, o peso dos cultivos de exportação inicia uma tendência crescente, chegando a 37\% em 2009. A cana-de-açúcar é outro cultivo que quase não recebe custeio do PRONAF, pois sua participação no total atinge 1\% somente a partir de 2006.

Essas informações confirmam que o PRONAF é de fato um programa voltado para a agricultura familiar: (1) seus recursos para custeio canalizam-se principalmente para os cultivos alimentares (em especial o milho), apesar da observação feita acima em relação a 2008-2009, (2) os cultivos de exportação apoiados são especialmente a soja e o café, onde a agricultura familiar tem alguma relevância na produção, e (3) a cana-de-açúcar, para cuja produção a agricultura familiar é pouco importante, praticamente não é apoiada pelo PRONAF até 2009. As quatro lavouras que, a partir de 2003, receberam mais de $70 \%$ dos recursos para custeio agrícola do PRONAF são milho, soja, café e mandioca, com tendência que milho e mandioca percam participação a partir de 2007 e soja e café ganhem.

13 Foram considerados entre os cultivos alimentares: milho, mandioca, feijão, arroz, trigo e batata.

14 Foram considerados entre os cultivos de exportação: fumo, soja, café e algodão. 
Entretanto, embora as desigualdades de acesso aos recursos do PRONAF tenham sido reduzidas, elas persistem em pelo menos dois aspectos importantes.

Em primeiro lugar, em 2002, a distribuição regional do montante de recursos do PRONAF concentrava-se basicamente na região Sul, que canalizava 56\% do total, de modo que as regiões Sul e Sudeste tinham acesso a 71\% dos recursos do programa, e o Nordeste obtinha 15\% do total. No período 2003-2006 (basicamente no Primeiro Governo Lula), ocorre uma notável e progressiva redução desta concentração, de maneira que em 2006 a região Sul tem uma acentuada diminuição no montante relativo de recursos que acessa (que cai para 39\%), a participação da região Sudeste passa para $20 \%$ do total nacional e o Nordeste aumenta sua participação para 26\%. Em 2006, portanto, Sul e Sudeste detinham 59\% do volume de crédito total do PRONAF.

Essa tendência de desconcentração é revertida em 2007, de modo que as participações relativas em 2008 voltam a aproximar-s e às constatadas em 2002, com exceção da região Sudeste. Assim, em 2008, a região Sul volta a canalizar $52 \%$ dos recursos totais do PRONAF, a participação do Nordeste torna a cair para $16 \%$ do total e a participação do Sudeste permanece inalterada em torno de $20 \%$ do total. Como consequência, a participação conjunta das regiões Sul e Sudeste retoma em 2008 (72\%), praticamente o mesmo valor que tinha em 2002 (71\%). Essa desigualdade de distribuição dos montantes do PRONAF entre o Sul e o Nordeste contrasta significativamente com a distribuição regional dos estabelecimentos agropecuários da agricultura familiar, já que o Nordeste detém cerca da metade do total desses estabelecimentos no país, enquanto a participação do Sul no total nacional é de $20 \%$. A distribuição é mais equilibrada para a região Sudeste, que possui $16 \%$ dos estabelecimentos da agricultura familiar e recebe 20\% do montante global do PRONAF.

A distribuição regional do número total de contratos do PRONAF no período 2002-2008 segue o mesmo padrão de desconcentração e reconcentração observado na distribuição do montante de recursos. Em 2002, para a região Sul convergiam $50 \%$ do total dos contratos, em comparação com 31\% na região Nordeste e $12 \%$ na região Sudeste. No período 2003-2006 é observada uma desconcentração nesta distribuição, de maneira que em 2006, a região Sul passa a ser responsável por 32\% do número total de contratos, a região Nordeste por $44 \%$ destes contratos e a região Sudeste por 18\%. A partir de 2007, esta tendência é revertida, a região Sul aumentando sua participação para 42\%, o Nordeste reduzindo para 32\% (mesmo nível de 2002-2003) e o Sudeste mantendo-se em $17 \%$. Note-se que essa reversão coincide com a redução do número total de 
contratos do PRONAF no país, e com o aumento do valor médio dos contratos, a partir de 2006 .

Em segundo lugar, permanece ou mesmo se acentua, nas safras agrícolas de 2002/2003 a 2007/2008, a desigualdade de acesso aos recursos do PRONAF entre os grupos de agricultores familiares, a favor dos grupos de maior renda e mais modernizados. A participação do Grupo A (basicamente de agricultores assentados pela reforma agrária), que era de cerca de $20 \%$ no montante de recursos executados pelo PRONAF na safra 2002/2003, caiu consideravelmente para cerca de 5\% em 2007/2008. O Grupo B, de agricultores com renda bruta anual familiar de até R\$ 4 mil, manteve uma participação constante, em torno de 7-8\% do total, enquanto o Grupo C (renda bruta anual familiar de mais de R \$ 4 mil até R $\$ 18$ mil) teve sua participação reduzida de $30 \%$ do total em 2002/2003, para $20 \%$ em $2007 / 2008$.

Os grupos que mais participam nos montantes do programa são o Grupo $\mathrm{D}$ (renda bruta anual familiar acima de $\mathrm{R} \$ 18$ mil até $\mathrm{R} \$ 50$ mil) e o Grupo E (renda bruta anual familiar acima de $\mathrm{R} \$ 50$ mil até $\mathrm{R} \$ 110$ mil), cuja participação conjunta passou de 51\% do total em 2003/2004 para 67\% em 2007/2008. Com duas particularidades: o Grupo D é o que tem a maior participação individual nos recursos do PRONAF (oscilando entre 41\% e 46\% no período) e o Grupo E foi o que apresentou o maior crescimento de participação, iniciando com apenas $9 \%$ do total em 2003/2004 e alcançando 23\% em 2007/2008.

Por fim cabe destacar as transformações ocorridas nas fontes que financiam o PRONAF, que de 2002 para 2008, apresentaram mudanças substanciais. Uma das alterações diz respeito ao FAT (Fundo de Amparo ao Trabalhador), que no final do Governo FHC mobilizava $2 / 3$ do montante de recursos do Programa e que, em 2008, passa a deter somente 10\%. Do mesmo modo, o Orçamento Geral da União (OGU), que representava mais de 30\% do volume do PRONAF em 2004, caiu para menos de 5\% em quatro anos. A fonte que cresceu abruptamente foi aquela oriunda dos recursos obrigatórios dos bancos (MCR 6.2 e MCR 6.4),

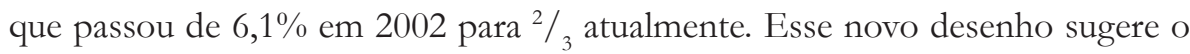
aumento do peso das instituições bancárias no direcionamento do PRONAF, dado que passaram a ser a principal fonte de recursos do programa.

Uma das mudanças sucedidas no Plano Safra 2008/09 - e que em alguma medida reflete essa nova conjuntura do PRONAF, no que tange às suas fontes foi a extinção dos grupos de agricultores C, D e E, uma classificação previamente adotada em função das diferenças de renda entre os agricultores. Essa classificação reconhecia, de alguma forma, as diferenças existentes no interior da categoria "agricultura familiar", tornando a política mais adaptada à realidade desse público. 
Com a supressão operada, essa diversidade deixa de ser considerada, em favor da facilidade e da agilidade na operacionalização dos contratos junto aos agentes financeiros, pois agora o beneficiário se encaixa no programa em função do montante de crédito que requer. Sem dúvida, essa nova situação é estratégica para os bancos, que podem, com mais facilidade, concentrar suas atividades nos agricultores mais capitalizados, que demandam contratos maiores, ficam sujeitos a taxas de juros mais elevadas e representam um menor custo operacional para a instituição financiadora.

\subsection{O PLANO SAFRA MAIS ALIMENTOS E POLÍTICAS DIFERENCIADAS PARA O MEIO RURAL}

A partir do ano agrícola 2008-2009, foi instituído pelo Ministério do Desenvolvimento Agrário (MDA) o Plano Safra Mais Alimentos, com o objetivo anunciado de formular uma nova política estruturante de longo prazo para a agricultura familiar, capaz de fazer frente à crise ocorrida no mercado externo e seus possíveis efeitos domésticos perversos, e de fortalecer, nesta conjuntura, o mercado interno, através da preservação do poder de compra dos consumidores nacionais pelo aumento da oferta de alimentos (objetivo central do Mais Alimentos).

O Plano Safra Mais Alimentos é composto por três medidas chamadas estruturantes de intervenção. A primeira foi a criação de uma linha especial de crédito para investimento de longo prazo com o objetivo de aumentar a produtividade dos agricultores familiares e, com isto, elevar a produção de alimentos. São recursos destinados ao investimento em infraestrutura produtiva, o que inclui ações como compra de máquinas e equipamentos, correção de solos, irrigação, armazenagem, entre outras.

Na verdade, a grande utilização desta linha de crédito do Mais Alimentos foi para a tecnificação dos agricultores familiares através da compra de tratores, máquinas e implementos agrícolas, o que tem acontecido principalmente na região Sul do país. O Gráfico 2 indica a evolução mensal acumulada do número de tratores financiados no período outubro/2008 a dezembro/2009. Observa-se uma explosão do financiamento de tratores para os agricultores familiares, pois no final do mesmo (dezembro/2009) o total acumulado de tratores financiados era quase 40 vezes o número financiado no início (outubro/2008).

Outro componente da linha de crédito do Mais Alimentos, que teve importante repercussão no segmento de agroindústria, foi o apoio financeiro dado às cooperativas de leite, especialmente no Rio Grande do Sul, através do 
PRONAF Agroindústria. Este apoio foi acompanhado por uma flexibilização das exigências anteriores para o acesso aos contratos coletivos (cooperativas e associações) do PRONAF Agroindústria para a cadeia de lácteos. Tal flexibilização abrandou o requisito das cooperativas e associações possuírem uma estrutura social composta de pelo menos $90 \%$ de agricultores familiares e terem uma participação de agricultores familiares na produção leiteira de 70\% do total. Essas exigências caíram para 70\% e 55\%, respectivamente.

Gráfico 2: Número de tratores financiados pelo Mais Alimentos por mês (dados acumulativos) - período outubro de 2008 a dezembro de 2009.

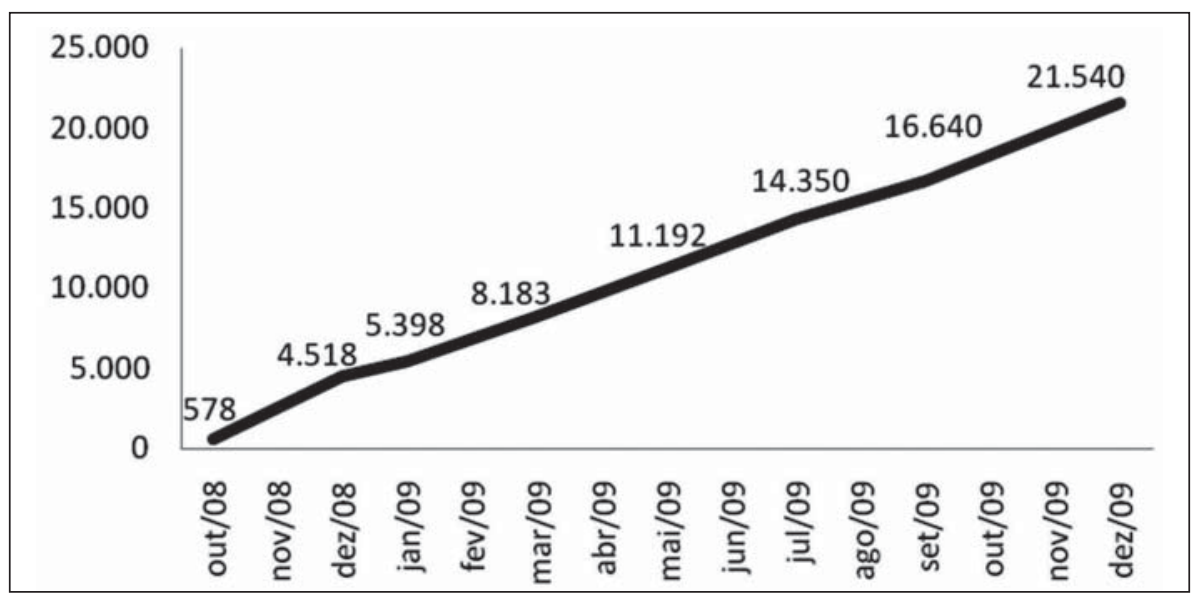

Fonte: SAF/MDA.

Além disso, o volume de recursos que pode ser acessado coletivamente também foi consideravelmente aumentado. De 2003 a 2007, o teto dos financiamentos coletivos era de R $\$ 720$ mil, sendo que cada agricultor individual poderia obter um financiamento de no máximo $\mathrm{R} \$ 18$ mil. Com o surgimento do Mais Alimentos, em 2008, é possível, no caso do processamento e industrialização de leite e derivados em cooperativas, chegar a um montante de até R $\$ 25$ milhões nos contratos coletivos e o limite individual passou a ser de até $\mathrm{R} \$ 28$ mil por sócio, segundo o Plano Safra 2008/09. Comparando o limite permitido de agricultores por projeto coletivo entre 2003 e 2010, é perceptível uma brusca alteração: até 2007/08 era possível incluir, no máximo, 40 pessoas por contrato e em 2008/2009 este número foi para quase 900 agricultores (um aumento de $2.231 \%$ ). Tudo indica, portanto, a ocorrência de uma grande mudança na linha PRONAF Agroindústria com o surgimento do Mais Alimentos, que se expressa, em particular, no propósito de apoiar, também, as grandes cooperativas e agroindústrias familiares. 
A segunda medida estruturante do Mais Alimentos diz respeito à assistência técnica e extensão rural, que aparece no plano como um suporte indispensável ao salto de produtividade da agricultura familiar almejado pelo programa. Neste sentido, o Mais Alimentos aparece como um instrumento para a institucionalização da Política Nacional de Assistência Técnica e Extensão Rural (PNATER) e para o aumento de recursos destinados à sua execução, com foco nas cadeias produtivas priorizadas pelo Mais Alimentos.

Com a implementação dos Planos Safra para a Agricultura Familiar, a intenção de apoiar novas experiências e de aumentar os recursos à disposição da ATER foi reafirmada. As informações disponíveis são muitas vezes contraditórias, mas segundo a SAF/MDA, na área de capacitação de extensionistas foram envolvidos 8 mil agentes, no período 2003-2007, os investimentos em capacitação foram da ordem de $\mathrm{R} \$ 50,6$ milhões, o número de extensionistas aumentou de 10.500 para 16.500 e o número de agricultores assistidos passou de 106 mil para 2 milhões nesse período. Segundo o Plano Safra Mais Alimentos 2009/2010, na safra 2008/2009, o processo de compatibilização da ATER com a pesquisa agropecuária possibilitou a disponibilização de tecnologias para as atividades das cadeias produtivas do leite, milho, mandioca, feijão, arroz, trigo, café, frutas, olerícolas, soja, suínos e pequenos animais e aves em todo o Brasil.

Por fim, em 11 de janeiro de 2010, o presidente Lula sancionou a Lei de Assistência Técnica e Extensão Rural que finalmente institui a PNATER, define os princípios e objetivos dos serviços de ATER e cria o Programa Nacional de Assistência Técnica e Extensão Rural na Agricultura Familiar e na Reforma Agrária (PRONATer).

A terceira medida estruturante do Mais Alimentos refere-se aos instrumentos de comercialização que beneficiam a agricultura familiar. Duas iniciativas são mencionadas no Plano Safra Mais Alimentos 2009/2010 e podem ter impacto importante, em especial a primeira, no acesso dos agricultores ao mercado: i) a promulgação da Lei 11.947, em 16/junho/2009, que estabelece que no mínimo 30\% dos recursos financeiros repassados pelo Fundo Nacional de Desenvolvimento da Educação (FNDE) ao Programa Nacional de Alimentação Escolar (PNAE) deverão ser destinados à aquisição de produtos da agricultura familiar; e ii) a criação do selo da agricultura familiar como um mecanismo de identificação/garantia para os consumidores de que os produtos adquiridos foram produzidos pela agricultura familiar. A implementação do estabelecido na Lei 11.947 poderá ter um impacto considerável sobre a demanda de produtos da agricultura familiar, dado o volume de recursos envolvido no FNDE, e obrigará os agricultores familiares a organizarem-se de forma adequada para conseguirem ampliar a oferta agrícola em quase todas as localidades do país. 
Não obstante tais iniciativas, os instrumentos principais particularmente enfatizados pelo plano são a Política de Garantia de Preços da Agricultura Familiar (PGPAF) e o Programa de Aquisição de Alimentos (PAA). Segundo o Mais Alimentos, o PGPAF passou a contemplar cerca de 30 produtos no ano agrícola 2009/2010, tendo elevado em mais de 40\% o limite anual do desconto de garantia do Programa, que passou de $\mathrm{R} \$ 3,5$ mil para $\mathrm{R} \$ 5$ mil por agricultor familiar. Além disso, a partir de 2008/2009 foram adotados preços mais elevados para produtos alimentares importantes para a cesta básica brasileira (trigo, arroz, feijão, milho, mandioca e leite), com o objetivo de proteger a agricultura familiar de quedas eventuais de preços desses produtos, em função da crise nacional e internacional agudizada em 2008.

O Programa de Aquisição de Alimentos (PAA), que foi criado como umas das ações estruturantes do Programa Fome Zero, ganhou crescente legitimidade social nos espaços institucionais em que há presença tanto de movimentos sociais e organizações não governamentais como de representantes de institutos de pesquisa e do meio acadêmico. Na verdade, o PAA conseguiu afirmar sua relevância para além do Fome Zero, na medida em que se propôs integrar as questões relativas ao acesso aos alimentos pelas populações carentes com a criação de mercado para os produtos oriundos da agricultura familiar. Neste sentido, a implementação do PAA representou um considerável aprendizado para os atores da política, tanto no que diz respeito à organização descentralizada do acesso aos alimentos como de sua produção, o que é um dos resultados cada vez mais esperados pela execução de qualquer política pública.

Com essa experiência, e com sua perspectiva intersetorial, o PAA passou a ser reconhecido como um programa ímpar, pois realiza na prática a integração entre a política de segurança alimentar e nutricional e a política agrícola voltada para a agricultura familiar, o que se reflete inclusive no fato de que é executado pelo Ministério de Desenvolvimento Social e Combate à Fome (MDS) e pelo MDA. Neste sentido, foi, desde o início, um instrumento importante na concepção dos Planos Safras da Agricultura Familiar, inclusive como um complemento do PRONAF a ser ampliado e consolidado, tanto em termos de recursos como de abrangência.

Os recursos desembolsados com o PAA no período 2003-2009 somam um total acumulado de $\mathrm{R} \$ 2.723$ milhões, o que é pouco significativo num país como o Brasil e sugere a enorme margem existente para o aumento de recursos do PAA no futuro ${ }^{15}$. Houve um crescimento contínuo da disponibilidade de recursos, mas

15 As informações sobre o PAA aqui utilizadas foram, em grande parte, obtidas em Grisa et al. (2009). 
o número de agricultores familiares beneficiados pelo programa ainda é muito modesto, pois o total acumulado no período 2003-2008 foi de cerca de 630 mil agricultores e o número de agricultores familiares atendidos em 2008 representava apenas $4 \%$ do total existente no país.

Se consideramos a distribuição dos recursos do PAA pelas grandes regiões do país, observa-se o nítido predomínio do Nordeste, que canalizou, em média, $54 \%$ do total dos recursos no período 2003-2007, em relação ao Sul (19\%) e ao Sudeste (18\%). Essas três regiões absorveram, em média, 91\% dos recursos do PAA neste período, a região Norte tendo uma participação de apenas 7\%. Note-se, entretanto, que se examinamos apenas o período 2005-2007, a região Nordeste perdeu participação, de 59\% em 2005 para 51\%, e o Sul ganhou posição, passando, respectivamente, de 14\% para 23\%, enquanto o Sudeste estabilizou-se em torno de 20\% (esta participação do Sudeste está associada principalmente a Minas Gerais). De qualquer modo, o foco principal do programa, no período considerado, foi a doação de alimentos para populações em condições de insegurança alimentar.

Ainda que seja difícil mensurar os resultados do Mais Alimentos neste momento, já é possível observar algumas tendências do programa a partir dos dados do PRONAF. Além do crescimento dos recursos disponibilizados e executados, o que se pôde visualizar, no período $2007 / 08$ e 2008/09, foi o incremento de $36 \%$ no valor médio dos contratos e de $48 \%$ nos valores destinados ao investimento. Outra característica que merece destaque é a concentração dos recursos no Sul do Brasil, em especial no Rio Grande do Sul. De 2007 para 2008 esse estado teve um crescimento de 43\% nos valores aplicados pelo PRONAF (enquanto que a média dos estados foi de $-2 \%$ ) e sua parcela nos recursos totais do Programa cresceu de $20 \%$ para 28\% - o maior desde o início do Governo Lula -, distanciando o Rio Grande do Sul dos demais estados (a diferença em relação ao segundo colocado, Paraná, é de 14\%).

Esses resultados são decorrentes, em grande medida, de três mudanças relevantes ocorridas no PRONAF a partir do Plano Safra Mais Alimentos: $1^{\mathrm{a}}$ ) a criação de uma linha de crédito de até $\mathrm{R} \$ 100$ mil para a aquisição de máquinas e implementos agrícolas, em especial tratores, onde os agricultores do Rio Grande do Sul, por estarem inseridos nas grandes cadeias agroindustriais e nos mercados agroalimentares, acabam tendo o perfil adequado e a disposição para acessar essa linha do programa; $2^{\mathrm{a}}$ ) a ampliação do volume de crédito do PRONAF Agroindústria para as cooperativas de leite e a flexibilização nas condições de enquadramento de seus beneficiários, o que resulta na inclusão no PRONAF de um novo público que está presente de forma significativa no Sul do país; e $3^{a}$ ) a extinção dos grupos de agricultores C, D e E do PRONAF, o que simplificou a 
operacionalização dos contratos junto aos agentes financeiros e facilitou o acesso dos agricultores mais capitalizados e modernizados.

Nesse sentido, ainda que o Mais Alimentos possa cumprir com os seus objetivos iniciais de fortalecer a produção doméstica e impedir a elevação dos preços dos alimentos para os consumidores, os efeitos colaterais não são desprezíveis, já no seu primeiro ano de execução. Assim, ao reconcentrar os resultados na região Sul e nos agricultores mais capitalizados, o PRONAF volta a deparar-se com problemas semelhantes aos existentes nos anos iniciais após a sua criação, os quais já tinham sido superados em grande medida no primeiro governo Lula, e que ressurgem a partir das modificações introduzidas pelo Plano Safra Mais Alimentos.

\subsection{DESENVOLVIMENTO TERRITORIAL E POLÍTICAS PÚBLICAS}

O Programa Territórios de Cidadania do Governo Federal foi instituído pelo Decreto de 25 de março de 2008, estando ainda numa fase de aprimoramento e consolidação de sua proposta de "superação da pobreza e das desigualdades sociais no meio rural, inclusive as de gênero, raça e etnia, por meio de estratégia de desenvolvimento territorial sustentável". Suas ideias-força principais são o conceito de território, a abordagem do desenvolvimento territorial sustentável e a proposta de articulação e coordenação de todas as políticas do governo federal destinadas aos territórios (envolvendo 22 ministérios). Segundo a Mensagem ao Congresso Nacional 2009, este programa constitui-se "na principal estratégia do governo para redução das desigualdades no meio rural, por meio de integração de políticas públicas".

O ponto de partida empírico dos Territórios de Cidadania é o Programa de Desenvolvimento Sustentável dos Territórios Rurais (PRONAT), criado pela Secretaria de Desenvolvimento Territorial (SDT) do MDA e oficializado pela Portaria $n^{\circ} 5$, de 18 de julho de 2005, durante o primeiro governo Lula, para a implementação de suas políticas de desenvolvimento rural tendo agora o território e não mais o município como sua referência de intervenção. Uma das inovações centrais dos dois programas é a criação de uma institucionalidade territorial, que congrega atores governamentais e não governamentais, com o objetivo de articulação de atores e de políticas públicas e de gestão social do desenvolvimento territorial sustentável, por intermédio dos Colegiados de Desenvolvimento Territorial. Existem atualmente no país 164 territórios rurais, oferecendo um quadro bastante diferenciado (de produção e de população rural) quando 
comparado àquele da produção agrícola de larga escala. Na maioria dos casos, os Territórios de Cidadania são territórios rurais de identidade com significativos índices de desigualdades econômicas e sociais.

Foram estabelecidos 120 Territórios de Cidadania, sendo que o Nordeste e o Norte juntos concentram cerca de $70 \%$ do número total de territórios e do volume programado de recursos. Em 2008, foi alocado para o Nordeste 48\% dos recursos totais programados e para o Norte $22 \%$. Em 2009, essas participações passaram, respectivamente, para 56\% e 17\%. As ações do governo federal nos Territórios de Cidadania estão classificadas em: direitos e desenvolvimento social; organização sustentável da produção; saúde, saneamento e acesso à água; educação e cultura; infraestrutura; apoio à gestão territorial; e ações fundiárias. Os recursos executados em 2008 pelo programa foram direcionados, por ordem de importância, para ações de direitos e desenvolvimento social (de grande peso no programa); saúde, saneamento e acesso à água; organização sustentável da produção; e infraestrutura. As ações que tiveram menor dotação de recursos executados foram apoio à gestão territorial e ações fundiárias. Os recursos programados para 2009 seguem, em ordem de importância (e desimportância), o ranking verificado em 2008.

\subsection{PROGRAMAS GOVERNAMENTAIS E DIVERSIDADE DA AGRICULTURA E DO MEIO RURAL BRASILEIROS}

Cabe ressaltar que uma atitude importante do governo Lula foi o reconhecimento da diversidade do mundo rural brasileiro, em termos de povos e de atividades, e a formulação de marcos legais e de políticas públicas com o objetivo de tirar muitas dessas populações e atividades da "invisibilidade social e política" e de contribuir para seu acesso aos direitos de cidadania garantidos pela Constituição de 1988 e para a criação de novos direitos quando inexistentes. Cabe frisar, neste particular, a atuação do Conselho Nacional de Desenvolvimento Rural Sustentável (CONDRAF) e sua preocupação em conceber uma política nacional de desenvolvimento rural sustentável que contemple adequadamente o reconhecimento da diversidade de povos e de atividades existentes nas diversas regiões do país.

Entre esses povos, por exemplo, as comunidades quilombolas passaram a ser assistidas pelo Programa Brasil Quilombola, que compromete o envolvimento de diversos ministérios, e que foi criado no marco do Decreto 4.887, de 20 de novembro de 2003. Nesse sentido, as políticas públicas do MDA têm dado relevo ao desenvolvimento sustentável de comunidades quilombolas, que começam a ter 
acesso a uma linha específica do PRONAF, e às ações de ATER e do PAA. Algo semelhante vem ocorrendo com as Comunidades Indígenas que, em conformidade com as determinações da Comissão Nacional de Política Indigenista, passam a ser objeto da Política Nacional de ATER e do II Plano Nacional de Reforma Agrária, através de projetos de ATER e de regularização fundiária implementados em áreas indígenas, e principiam a ter acesso ao PRONAF e ao PAA.

Em relação às mulheres rurais, o Programa Nacional de Documentação da Trabalhadora Rural, considerado estratégico para a inclusão das mulheres nas políticas direcionadas à agricultura familiar e à reforma agrária, atendeu, ao todo, cerca de 360 mil mulheres no período 2004-2008, de modo que em 2008 o número de mulheres incluídas foi 10 vezes superior ao do início do período. Ademais, o II PNRA estabeleceu a obrigatoriedade da titulação conjunta da terra, um direito das mulheres já previsto na Constituição de 1988, e no PRONAF, onde se destaca a linha de crédito especial PRONAF Mulher, cresceu a participação das mulheres tanto no volume total de recursos (de 11\% em 2001/2002 para $17 \%$ em 2006/2007) como no número total de contratos (de $10 \%$ para $30 \%$ no mesmo período). Por fim, as mulheres também tiveram acesso à política de ATER, através de projetos específicos para as mulheres rurais, a cujas ações se soma o Programa de Organização Produtiva das Mulheres Rurais, voltado diretamente para o fortalecimento das organizações produtivas de trabalhadoras rurais.

Vale mencionar, por fim, dois outros tipos de programas que, embora não se enquadrem no rol das políticas setoriais agrícolas e agrárias stricto senso, compõem um mix de políticas públicas diferenciadas que tem desempenhado papel estratégico para o setor rural e para o reconhecimento da diversidade de grupos sociais aí presentes.

O primeiro tipo é o dos chamados programas ou políticas sociais, onde se destaca o Programa de Previdência Social Rural, do Ministério da Previdência Social (MPS), que desde o início dos anos 1990 vem possibilitando o acesso de uma parte importante da população rural aos benefícios continuados da previdência, em especial ao conjunto de aposentadorias no regime de economia familiar. A continuidade dessa política durante os dois mandados do governo Lula pode ser considerada uma contribuição importante na manutenção e na reprodução de boa parte dos agricultores familiares, em especial aqueles localizados na região Nordeste. Nesta mesma direção, inúmeros estudos têm chamado a atenção para a relevância e o impacto do Programa Bolsa Família, do MDS, sobre as áreas rurais do país, especialmente sobre a expansão da capacidade de acesso dos beneficiários do programa aos alimentos e à melhoria das condições nutricionais das famílias. 
O segundo tipo de políticas tem a ver com os programas de infraestrutura. Neste particular, cabe lembrar o impacto da política de Habitação Rural e do Programa de Eletrificação do Campo, que começaram a ser executados já no primeiro mandato. Em particular, o Programa Luz para Todos, do Ministério de Minas e Energia, vem garantindo uma melhoria substantiva nas condições de vida e de produção da população rural. Finalmente, cabe lembrar, ainda, o Programa de Construção de Cisternas, em especial na região semiárida, no Nordeste brasileiro. Nesse caso, porém, os créditos devem-se mais aos esforços da rede de organizações não governamentais da Articulação do Semiárido (ASA) do que propriamente às iniciativas governamentais.

A política social e de distribuição de renda do governo Lula tem sido um dos pontos fortes que alimentam o projeto democratizante, tanto nas cidades como no campo. Por um lado, como mencionado acima, um conjunto de programas sociais, dentre os quais se destaca o Bolsa Família, melhorou as condições de vida das parcelas mais desprotegidas da população e, ao mesmo tempo, quando somados aos benefícios da previdência social rural e de outras políticas destinadas aos agricultores familiares, propiciou a vitalização de pequenas cidades e comunidades rurais no interior do Brasil, em especial no Nordeste, aumentando a renda, o emprego e o consumo de suas populações.

Por outro lado, o aumento do salário mínimo real durante o governo Lula, juntamente com a continuidade do processo de desconcentração regional da produção (industrial e agrícola) nacional, que já vem de longe, estimulou não apenas uma retomada do crescimento econômico em 2007 - com uma taxa real anual de crescimento do PIB (a preços de 2008) de 5,7\%, que se manteve em 5,1\% em 2008, não obstante à crise financeira mundial desencadeada a partir de setembro -, como uma aparente mudança no padrão deste crescimento.

Como defende Bacelar (2008b, p. 26), em 2007 "quem puxou o crescimento do PIB no Brasil não foram mais as exportações, foi o consumo interno e o investimento. E dentro do consumo interno, foi o consumo da base da pirâmide social ... que já tem mais de 80 milhões de consumidores ... E, regionalmente, quem puxou o consumo na base da pirâmide foram os estados mais pobres do Brasill", no Nordeste e no Norte $^{16}$. Segundo Bacelar (2008a, p. 9-10), este aumento do consumo das camadas de baixa renda explica-se pela melhoria da renda do trabalho no período, que se deve à redução da inflação, ao aumento do salário mínimo real

16 De acordo com Bacelar (2008b, p. 26 e 113), o crescimento das vendas no comércio varejista do país, no período 2003-2007, foi liderado pelos estados do Nordeste, seguidos de estados do Norte. 
e à elevação do crédito ao consumidor e o alargamento de seus prazos, além do impacto do aumento do emprego no período.

Se essa mudança no padrão de crescimento da economia for confirmada e puder manter-se nos próximos anos ${ }^{17}$, representará um extraordinário incentivo para o fortalecimento do projeto democratizante no meio rural, através, entre outros fatores, do aumento da demanda interna de alimentos e de seus efeitos sobre a expansão da agricultura familiar no país.

Finalmente, é preciso destacar a recriação do Conselho Nacional de Segurança Alimentar e Nutricional pelo governo Lula, depois de sua extinção pelo governo FHC, após um curto período de vida durante o governo de transição de Itamar Franco. Embora a ênfase na produção agrícola para exportação por parte do governo coloque uma sombra de dúvida sobre a profundidade da prioridade à segurança alimentar e nutricional, é indiscutível que a existência do CONSEA, ligado à Presidência da República, representa também um apoio não desprezível à temática da segurança alimentar e nutricional, pelo e dentro do governo.

Do ponto de vista do projeto democratizante no meio rural e sua manifestação através da construção de um modelo alternativo de desenvolvimento rural baseado na agricultura familiar, a temática ou a meta da segurança alimentar e nutricional é fundamental porque combina e elabora alguns componentes essenciais para o modelo alternativo: (1) relativiza as vantagens de uma agricultura voltada para a exportação; (2) destaca o direito à alimentação de qualidade como um direito primário da população; (3) defende, como consequência, a prioridade da produção interna de alimentos de qualidade, num volume compatível com o pleno acesso a esse direito: num país das dimensões do Brasil, a segurança alimentar e nutricional nunca vai poder ser atendida de forma permanente e satisfatória através das trocas internacionais; (4) a produção doméstica é priorizada ademais porque incorpora a diversidade cultural existente no país e que se expressa através de diferentes padrões regionais de alimentação e de tipos de alimentos, o que seria perdido com a homogeneização forçada imposta por grandes volumes de importações; (5) como decorrência, o fortalecimento e a consolidação da agricultura familiar, bem como a melhoria da renda das populações urbanas e rurais, são objetivos centrais da política de SAN; e (6) o tema da segurança alimentar e nutricional não é um tema setorial, mas multissetorial e multidimensional, exigindo portanto um tratamento que

17 Embora a crise mundial tenha afetado negativamente a economia brasileira, especialmente seu setor exportador, seus efeitos deletérios foram menores do que em outras economias do sistema internacional, em parte devido a este crescimento do mercado interno. Embora o PIB real (a preços de 2008) não tenha aumentado em 2009, as previsões do sistema produtivo brasileiro, segundo IPEA (2010), eram de um crescimento de 5,2\% em 2010. 
contemple, como exigência básica, a necessidade de articulação de políticas públicas de diferentes áreas e origens setoriais.

Não obstante os avanços feitos na direção da consolidação do projeto democratizante, a importância do agronegócio continuou intocada na economia e na política brasileiras, em função da manutenção de seu papel estratégico para o ajustamento da conta de transações correntes da balança de pagamentos, de modo que, apesar das mudanças fundamentais ocorridas na política externa brasileira, o agronegócio continua determinando a agenda de negociações comerciais internacionais sobre agricultura do Brasil. Sua expansão, na primeira década dos anos 2000, foi grandemente estimulada pela tendência à elevação dos preços das commodities agrícolas no mercado internacional, devida especialmente ao aumento da demanda e determinada pela entrada maciça no comércio mundial de países da Ásia, como a Índia e, muito especialmente, a China. O caso da soja foi marcante neste sentido, mas não único. Além disso, a expansão dos produtos de exportação foi também garantida pela política econômica governamental e pela prática recorrente de renegociação e de rolagem das dívidas dos grandes produtores ${ }^{18}$.

Este conjunto de estímulos nacionais e internacionais fizeram com que as exportações do que Leite (1996) chamou de "macro-setor agrícola" tenham atingido uma média de participação nas exportações totais de 37\%, no período 2003-2009, mantendo-se praticamente igual à média do período 1997-2002 (38\%), embora tenha chegado a $43 \%$ em $2009^{19}$. Ademais, a balança comercial do "macro-setor agrícola" brasileiro tem mantido a característica estrutural de ser permanente e crescentemente superavitária, pois, ao contrário do que ocorre com o setor industrial, o valor das importações mantém-se relativamente reduzido, em termos absolutos, e permanece razoavelmente inalterado ou aumenta a um ritmo muito inferior ao das exportações. No período 2002-2008 o valor FOB do superávit da balança comercial do "macro-setor agrícola" elevou-se de cerca de US\$ 19 bilhões em 2002 para US\$ 60 bilhões em 2008 (216\%).

Note-se, no entanto, que apesar do enorme aumento das exportações do setor agrícola, ocorreu no Governo Lula uma elevação significativa da participação

18 Segundo informações reproduzidas por Heredia, Palmeira e Leite (2009, p. 23), “de 1997 a 2006, o custo público com a rolagem da dívida atingiu o valor de $\mathrm{R} \$ 10,433$ bilhões, enquanto o subsídio ao exercício das políticas setoriais chegou a $\mathrm{R} \$ 16,328$ bilhões. Ou seja, praticamente $40 \%$ dos recursos governamentais com essas despesas setoriais "indiretas" foram direcionados ao saneamento das dívidas do agronegócio". Ademais, segundo os autores, o grosso do endividamento concentra-se em torno de 1.800 contratos (num universo de 3 milhões de agricultores).

19 As exportações do "macro-setor agrícola" correspondem aos níveis de agregação 1, 2 e 4 da Nomenclatura Brasileira de Mercadorias (NBM) e incluem: agropecuária, extrativismo vegetal, beneficiamento de produtos agropecuários, agroindústrias de primeiro e segundo processamento e produção de bens de consumo final (ver também Delgado (1997)). 
dos produtos que fazem parte do nível 1 da NBM (agricultura, pecuária e extrativismo vegetal) e uma retração do peso na pauta de exportações dos produtos mais elaborados e com maior valor adicionado, que são os produtos de bens de consumo final e os originados em agroindústrias de segundo processamento (nível 4 da NBM). Assim, os produtos básicos passam a representar cerca de 50\% do valor das exportações do setor agrícola em 2008-2009, contra 36-37\% no período 1997-2000, enquanto os produtos de maior processamento e valor adicionado têm seu peso reduzido na pauta de cerca de 30\% em 1997 para 22\% em 2008-2009. Este comportamento da pauta de exportações reflete, sem dúvida, a explosão da soja e do ganho de peso da China no destino das exportações - que passou a concentrar 13\% das exportações brasileiras em 2009, contra 2\% em 2002 -, bem como acompanha um processo semelhante que ocorre na própria cadeia da soja, cujas exportações têm apresentado uma tendência a concentrarem-se no produto em grão, em detrimento do farelo, óleo etc., de maior processamento e valor adicionado. Essas características da evolução recente da balança comercial têm sugerido a ocorrência de um processo de "primarização" do comércio exterior do país (uma dependência maior dos produtos primários em relação aos industrializados), o que introduz a possibilidade de uma perigosa instabilidade na balança de pagamentos, cujas exportações dependem do comportamento dos produtos primários (especialmente da evolução de seus preços) e as importações expressam o comportamento dos produtos industrializados.

A expansão do agronegócio e de seus produtos de exportação em direção ao Norte e à região amazônica, pressionou de forma considerável o desmatamento na região, assim como a estrutura fundiária regional, provocando recorrentes conflitos fundiários com pequenos produtores, posseiros, seringueiros e povos indígenas. Nesse aspecto, os conflitos no campo não foram atenuados na região Amazônica durante o governo Lula e a manutenção do agronegócio como principal elemento de ajuste das contas externas do país teve como contrapartida uma perigosa, e controversa, ameaça à preservação ambiental e à segurança das populações rurais na região, que se expressa inclusive por meio de intensa pressão sobre a legislação ambiental existente (Código Florestal, Áreas de Reserva Legal e de Preservação Permanente, Sistema Nacional de Unidades de Conservação). A iniciativa recente do governo de enfrentar as questões relativas à regularização fundiária na região Norte através do Programa Terra Legal, lançado em 2009, está apenas iniciando, mas tem sofrido pesadas críticas dos movimentos sociais no sentido de que venha a legalizar e a legitimar parte do processo de grilagem e de apropriação indevida de terras devolutas que ocorre (historicamente) na região, especialmente nos estados de Mato Grosso, Pará e Rondônia. 
De modo geral, a continuidade do aumento da produção de produtos agropecuários de exportação nos dois governos Lula, e a liderança do agronegócio nesse processo, praticamente eliminou qualquer preocupação mais consistente e permanente por parte do governo com a mudança do padrão predominante de modernização da agricultura, não obstante a sua preocupação anunciada, com a redução das desigualdades no campo, em especial através da inclusão de agricultores até aqui excluídos do processo de modernização. A decisão governamental de permitir o crescimento da produção de produtos transgênicos, em particular da soja, não obstante a vigorosa oposição de todos os movimentos sociais rurais e de inúmeras ONG é um reflexo dessa posição. Ademais, essa omissão, por um lado, manteve inalterados os processos de degradação ambiental e de exclusão social associados a esse padrão de modernização. Por outro, pressiona negativamente, em particular, os agricultores familiares tecnificados, usualmente produtores de produtos de exportação, e que se encontram, em geral, endividados, com custos de produção elevados e com consideráveis problemas ambientais. O Programa Plano Safra Mais Alimentos, lançado em 2008, como vimos, para fortalecer a agricultura familiar diante da crise internacional, pode talvez ser melhor percebido neste contexto. Aparentemente, não foge ao modelo predominante de modernização agrícola, pois levou a uma reconcentração dos recursos do PRONAF na região Sul, estimulou o aumento da "tratorização" entre os agricultores familiares desta região e facilitou o acesso aos recursos creditícios destinados à agricultura familiar às cooperativas e agroindústrias familiares de maior porte do sul do país. Por outro lado, é tentador pensar o programa como uma tentativa de atrair politicamente os agricultores familiares modernizados desta região, que, inseridos no modelo de modernização agrícola predominante, têm vivenciado experiências de endividamento, degradação ambiental e crise das cooperativas agroindustriais a que estão associados. Neste sentido, o Mais Alimentos aparece como uma política governamental específica para um tipo de agricultor familiar que se considerava muitas vezes abandonado pelo governo Lula.

As informações existentes parecem indicar uma inflexão na importância assumida pela reforma agrária no segundo mandato do governo Lula, quando o tema parece ter perdido prestígio dentro do governo. Algumas indicações parecem respaldar esta avaliação. Embora as metas do II Plano Nacional de Reforma Agrária (II PNRA) fossem relativamente tímidas, seus resultados ficaram muito aquém: o número de famílias assentadas caiu continuamente desde 2005 (seu ápice no Governo Lula), passando de 101 mil para 87,5 mil em 2006, 29 mil em 2007 e 21,5 em 2008 (dados do INCRA). Na mesma direção, o governo Lula praticamente desistiu do mecanismo de desapropriação de terras para a reforma agrária, pois 
a participação das terras desapropriadas no total das terras arrecadadas para a reforma agrária caiu de 40\% no segundo Governo FHC, para 5\% no primeiro governo Lula (IPEA). Essa situação parece refletir a desistência do governo em tentar promover alterações na legislação sobre reforma agrária em vigor, frente às enormes resistências encontradas, de modo que os índices de produtividade (que indicam se um imóvel rural é passível ou não de desapropriação), por exemplo, continuam mantidos em seus níveis de 1975.

Apesar de que o tratamento da reforma agrária exija, sem dúvida, uma análise mais complexa, queremos observar aqui que, não obstante os importantes esforços empreendidos para o fortalecimento da agricultura familiar, a relativa perda de prestígio da reforma agrária no governo Lula parece corroborar, na prática da gestão das políticas, uma concepção que separa a reforma agrária das políticas destinadas à agricultura familiar, o que o aproxima, neste particular, do governo FHC e tende a acentuar a diferença e o isolamento desses dois componentes do projeto democratizante no meio rural, como dois movimentos estanques e sem interação.

\section{COMENTÁRIOS FINAIS}

Para encerrar este texto, dando continuidade à trajetória seguida em sua elaboração, vamos chamar a atenção para três conjuntos de questões que representam obstáculos, desafios e oportunidades para avançar na concepção e na implementação do processo de desenvolvimento rural no Brasil.

Primeiro obstáculo. Como o texto procurou argumentar, o maior obstáculo ao desenvolvimento rural no Brasil vem do peso político do agronegócio e do papel central que desempenha na estratégia de especialização na exportação de produtos agropecuários como forma predominante de ajustamento da conta de transações correntes do balanço de pagamentos. Este é o papel da agricultura na economia, definido e consolidado pelo projeto neoliberal e que tem sua raiz nos desequilíbrios econômicos desencadeados pela crise externa, na década de 1980, e na escolha de um caminho de liberalização e de integração da economia à globalização, na década de 1990. Essa opção dos anos 1990, relançou a velha ideia da vocação agrícola e agroexportadora do Brasil, travestida agora de agronegócio, e o fez em detrimento de uma vigorosa e diversificada retomada do processo de industrialização e do peso das exportações industriais e de serviços na pauta de exportações brasileiras. 
Este ajustamento externo, ancorado no agronegócio não é um problema somente para as condições de viabilização do desenvolvimento rural. Ele é igualmente um problema de longo prazo para a continuidade do crescimento da economia brasileira, que, nessas condições, não tem conseguido manter taxas elevadas de crescimento (em torno de 5\% a.a.) ao longo do tempo, como se tornou a regra desde a década de 1980. Como diz Delgado (2008, p. 30), "a forte especialização na exportação primária, que a presente estratégia externa contém, pode conduzir a um tríplice desequilíbrio: desequilíbrio nas transações externas, pressão crescente sobre o preço dos alimentos, cuja equação conservadora consiste em retornar a economia aos patamares da estagnação, monitorada pela política de juros do Banco Central".

Ademais, como aconteceu na década de 1970, períodos de grande expansão das exportações agropecuárias são também períodos de pressão sobre as áreas ocupadas pela produção de alimentos, inclusive em função da elevação do preço da terra, o que tende a estagnar a produção e aumentar os preços dos alimentos. Situação que pode ser dramatizada quando coincide com processos especulativos no sistema internacional, como ocorreu em 2008. O lançamento do Plano Safra Mais Alimentos tentou enfrentar este risco de elevação dos preços dos alimentos, mas o fez promovendo, aparentemente, os segmentos mais modernizados da agricultura familiar localizados no Sul do país, e com consequências sobre a política pública para a agricultura familiar, em especial o PRONAF, que merecem investigação mais cuidadosa.

Com a expansão que já está acontecendo na produção de agrocombustíveis, e que provavelmente vai se acentuar no futuro, dificilmente a continuidade do aumento da produção para exportação nos termos em que está ocorrendo deixará de provocar uma grande pressão altista sobre o preço da terra, correndo o risco de desestruturar a produção interna de alimentos, a menos que seja protegida pela intervenção governamental reguladora. Se houver uma estagnação na produção de alimentos, a tendência à elevação dos preços será inevitável e, mantido o ajustamento externo via exportações agropecuárias, o mais provável é que a política macroeconômica seja utilizada para reduzir o crescimento da economia, diminuindo, como consequência, a demanda doméstica e o mercado interno.

Eis aqui, portanto, um enorme desafio para o projeto democratizante. Como definir uma estratégia para lidar com o agronegócio na formulação e na implementação de um mix de políticas de desenvolvimento rural sustentável? A tentativa de elaborar uma estratégia deste tipo parece urgente, pois as características, a profundidade e a abrangência do desenvolvimento rural no país vão depender do tipo de relação que estabeleça com o agronegócio, na medida em que esses 
dois projetos nunca vão ser estanques, e estão continuamente disputando o espaço rural e as políticas públicas entre $\mathrm{si}^{20}$.

Há outro desafio para o projeto democratizante, a que cabe chamar atenção. Vimos que, na década de 1990, este projeto foi estruturado para o meio rural, em torno da ideia de reforma agrária e de um modelo alternativo de desenvolvimento rural baseado na agricultura familiar e na reforma agrária, e que seus personagens principais foram os sem-terra, os assentados e os agricultores familiares. Vimos também que o olhar sobre o rural se complexificou significativamente a partir de então, com o surgimento de novos personagens que saíram da "invisibilidade" e que reivindicam seu reconhecimento não apenas pela sociedade e pelo Estado, mas também pelo próprio projeto democratizante. O documento CONDRAF (2008), por exemplo, deixa claríssima a sua emergência.

Que consequências a incorporação desses novos personagens traz para o projeto democratizante, em termos de sua condução e de suas propostas? Continuam a reforma agrária e o desenvolvimento rural baseado na agricultura familiar sendo as ideias-força principais em torno das quais se podem aglutinar todos os personagens identificados hoje no mundo rural? É possível e aceitável pensar em hegemonias na condução do projeto democratizante? É possível e aceitável tentar superar a fragmentação que a luta pelo reconhecimento de novas identidades naturalmente produz? Quais as consequências dessa situação para a construção de políticas de desenvolvimento rural adequadas ao fortalecimento do projeto democratizante no meio rural? As demandas dos diferentes segmentos têm sido progressivamente explicitadas em diferentes fóruns e conferências públicas. O grande desafio para o futuro será tentar acordar quais são os elementos que formam o núcleo central deste mix de políticas, em torno do qual os instrumentos vão ser definidos, e a partir do qual as diversas demandas vão ser organizadas.

Por fim, uma oportunidade para o fortalecimento do projeto democratizante para o mundo rural e para o desenvolvimento rural no país. Mencionamos que a política social e de aumento do salário mínimo, implementada pelo governo Lula, promoveu um revigoramento das economias de pequenas cidades do interior do Brasil, muitas delas rurais, aumentando a renda e o consumo de seus habitantes e

20 Não há razão para que essa estratégia tenha um caráter meramente conflitivo. Por exemplo, as possibilidades de negociação e de acordos porventura existentes e a insistência na transparência nas relações do agronegócio com as agências e políticas do Estado devem ter seu lugar na mesma. Neste sentido, para avançar na construção da estratégia é indispensável "abrir" o agronegócio, deixar de considerá-lo como um bloco monolítico (como fizemos neste ensaio para simplificar a argumentação), de modo a compreender a diversidade de participantes e interesses, as tensões e conflitos presentes e potenciais, e as especificidades territoriais (para perceber a riqueza que pode estar contida nesta abordagem, consulte-se, por exemplo, Heredia, Palmeira e Leite (2009)). O mesmo, é claro, deve ser feito para a agricultura familiar e as demais populações e povos existentes no rural. 
gerando efeitos positivos territoriais e microrregionais. Mencionamos também a constatação de Bacelar (2008a; 2008b), de que o vigoroso crescimento da economia em 2007 e 2008 foi fundado no investimento e no consumo doméstico, sendo que o incremento do consumo foi principalmente o dos consumidores da base da pirâmide social, localizados particularmente no Nordeste e no Norte do Brasil.

Se essa tendência for confirmada por outras avaliações, representa uma grande oportunidade para o projeto democratizante para o mundo rural e para as possibilidades de desenvolvimento rural no país, não obstante o agronegócio. Distribuição da renda, geração de empregos e crescimento do mercado interno são janelas de oportunidades que o comportamento da economia abre para o desenvolvimento rural, especialmente através de seus efeitos sobre a produção de alimentos, o emprego rural e uma série de outras repercussões importantes sobre o mundo rural. A manutenção dessa política deveria ser uma reivindicação fundamental do projeto democratizante.

\section{REFERÊNCIAS}

BACELAR, T. Entrevista. Desafios, p. 8-14, jul. 2008a. Palestra. In: CONFERÊNCIANACIONALDEDESENVOLVIMENTO RURAL SUSTENTÁVEL E SOLIDÁRIO, 1. Por um Brasil com Gente. Olinda, 2008. Relatório... Brasília: CONDRAF, 2008b. p. 21-30 e 112-3.

BENETTI, M. D. Globalização e desnacionalização do agronegócio brasileiro no pós-1990. Porto Alegre: FEE, 2004. (Documentos FEE, n. 61)

BRUNO, R. Um novo campo de conflito agrário. As associações patronais em defesa da propriedade e o movimento de ocupação de terra durante a Nova República. In: BRUNO, R. et al. Um Brasil ambivalente. Agronegócio, ruralismo e relações de poder. Rio de Janeiro/Seropédica: Mauad X/EDUR-UFRRJ, 2009. p. 63-107.

\section{CONDRAF. Relatório Final da $1^{a}$ Conferência Nacional de Desenvolvimento}

Rural Sustentável e Solidário (Olinda/PE, 25-28 jun. 2008). Por um Brasil com Gente. Brasília: MDA/CONDRAF, 2008.

DAGNINO, E. Confluência perversa, deslocamentos de sentido, crise discursiva. In: GRIMSON, A. (Comp.). La cultura en las crisis lationamericanas. 1. ed. Buenos Aires: Clacso, 2004. p. 195-216. 
DELGADO, G. da C. Tensões externas e internas sobre os preços dos alimentos: fatores explicativos. In: Abastecimento e segurança alimentar. O crescimento da agricultura e a produção de alimentos no Brasil. Brasília: CONAB, 2008. p. 23-32.

A questão agrária no Brasil, 1950-2003. In: JACCOUD, L. (Org.). Questão social e políticas sociais no Brasil contemporâneo. Brasília: IPEA, 2005. p. 51-90.

Agricultura e comércio exterior: rumo da regulação estatal e suas implicações para a segurança alimentar. Rio de Janeiro: Rede Interamericana Agricultura e Democracia; Fórum Alternativas para a Agricultura Brasileira, 1994.

DELGADO, G. da C.; FERNANDES FILHO, J. F. Determinantes da queda recente do preço da terra no Brasil. Economia. Ensaios, v. 12, n. 2 e v. 13, n. 1, p. 17-35, jul./dez. 1998.

DELGADO, N. G. Política econômica, neoliberalismo e agricultura. In: COSTA, L. F. de C., FLEXOR, G.; SANTOS, R. (org.). Mundo rural brasileiro. Ensaios interdisciplinares. Rio de Janeiro: UFRRJ/Mauad X, 2008. p. 199-237.

Considerações acerca da inserção do Brasil no sistema agroalimentar internacional. Indicadores Econômicos FEE, v. 25, n. 3, p. 148-168, nov. 1997.

GOLDIN, I.; REZENDE, G. C. de. A agricultura brasileira na década de 80: crescimento numa economia em crise. Rio de Janeiro: IPEA, 1993. (Série IPEA, v. 138)

GRISA, C. et al. O Programa de Aquisição de Alimentos (PAA) em Perspectiva: Apontamentos e Questões para o Debate. Rio de Janeiro, ActionAid Brasil/OPPA-CPDA, mimeo, 24 p. 2009

HEREDIA, B.; PALMEIRA, M.; LEITE, S. P. Sociedade e economia do "agronegócio" no Brasil. In: ENCONTRO ANUAL DA ANPOCS, 33. Caxambu, GT 41, 2009. Anais... ANPOCS, 2009. 35p.

INSTITUTO DE PESQUISA ECONÔMICA APLICADA. Sensor Econômico, Brasília, v. 2, n. 1, 1 Bim. 2010.

LEITE, S. P. Inserção internacional e financiamento da agricultura brasileira (1980-1996). 1998. Tese (Doutorado em Economia) - Instituto de Economia, Universidade Estadual de Campinas, Campinas 1998. 
MEDEIROS, L. S. de. "Sem-terra", "assentados", "agricultores familiares": considerações sobre os conflitos sociais e as formas de organização dos trabalhadores rurais brasileiros. In: GIARRACCA, N. (Comp.). ¿Una nueva ruralidad en América Latina? Buenos Aires: CLACSO, 2001. p. 103-128.

MEDEIROS, L. S. de. Movimentos sociais, disputas políticas e reforma agrária de mercado no Brasil. Rio de Janeiro: CPDA/UFRRJ; UNRISD, 2002. MELO, F. H. de. Liberalização comercial e agricultura familiar no Brasil. In: ACTIONAID. Comércio internacional, segurança alimentar e agricultura familiar. Rio de Janeiro: ActionAid Brasil/Rebrip, 2001. p. 7-44.

SOARES, A. C., ROMANO, J. O., DELGADO, N. G. Relevance of special and differential treatment for strengthening family farming and combating poverty in Brazil. Paper preparado para o United Nations Development Program. 2004. 29p.

TAVARES, M. da C. A retomada da hegemonia norte-americana. In: TAVES, M. da; FIORI, J. L. (Orgs). Poder e dinheiro. Uma economia política da globalização. Petrópolis: Vozes, 1997. p. 27-53. 
